ASHER GABRIEL EMANUEL

\title{
The CONSTITUTIONALITY OF DEFAULT ARBITRATION
}

LLM RESEARCH PAPER

LAWS 525 - INTERNATIONAL COMMERCIAL CONTRACTS

SUBMITTED FOR THE LLB(HONS) DEGREE

TE WHARE WĀNANGA O TE ŪPOKO O TE IKA A MĀUI

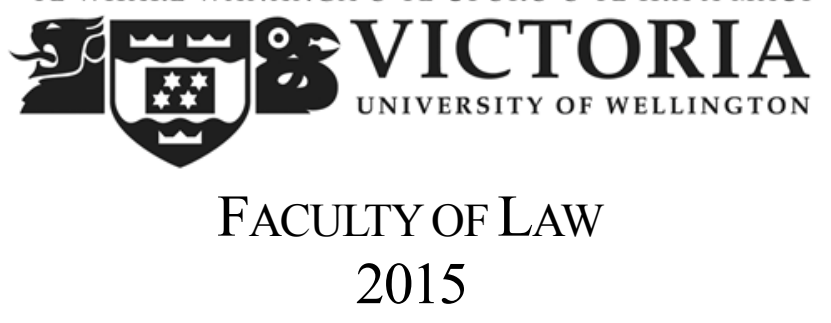



A proposed Bilateral Arbitration Treaty would subject international commercial disputes between enterprises in signatory states' jurisdictions to arbitration unless the parties agreed to the contrary. This marks a substantial departure from conventional understandings of arbitration as based on the consent of the parties. More importantly, the policy would modify the jurisdiction of the courts, removing a large number of disputes to offshore tribunals subject to minimal judicial oversight. This paper explores the constitutional propriety of such a policy, with particular attention paid to the principles of the separation of powers, the rule of law, public provision of essential State functions, open justice, and democracy. These constitutional principles would be subverted if the policy were to operate within the existing regulatory framework for arbitration. The paper makes recommendations for possible modifications to the policy that would make it a better fit with the constitution.

This paper, excluding bibliography, non-substantive footnotes, appendices, table of contents, and abstract, comprises approximately 17,640 words. 


\section{TABLE OF CONTENTS}

I Introduction ................................................................ I

II Overview of the BAT .................................................... 3

A Functional effect of the BAT .......................................... 5

1 General provisions .................................................... 5

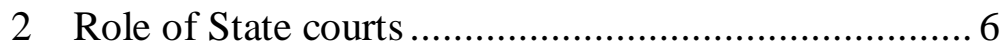

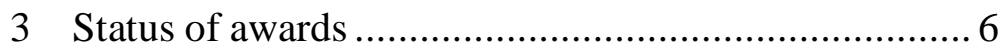

4 Confidentiality …………………….......................... 7

B Conformity with New Zealand arbitration law ................ 7

C Opportunities for review .............................................. 9

D Summary............................................................... 9

III What is meant by "constitutionality"............................... 9

A The 'is' of the constitution ............................................... 13

$B \quad$ The 'ought' of the constitution ......................................... 14

IV Compatibility with the New Zealand Bill of Rights Act... 15

A Natural justice........................................................ 16

B Judicial review ........................................................ 18

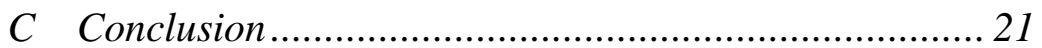

$V \quad$ The separation of powers................................................. 22

A Judicial power under written constitutions .................... 24

B Judicial power in Westminster constitutions .................. 27

C Effect of BAT on judicial power.................................... 33

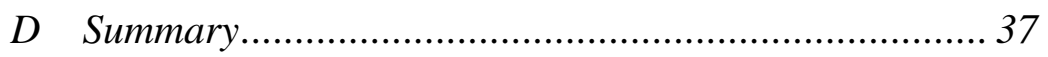

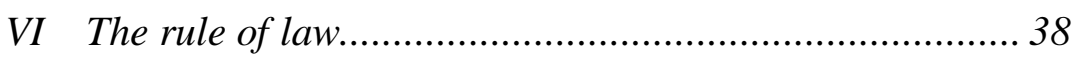

A Preserving the interpretative role ................................... 40

$B \quad$ Review of government action .......................................... 43

C Voluntariness and the rule of law................................. 45

D Constitutional consequences ......................................... 47

VII Privatisation of State function ......................................... 49

VIII Open justice and democracy ........................................ 52

A Openness and accountability ........................................ 52

B Public interest in particular laws.................................. 56

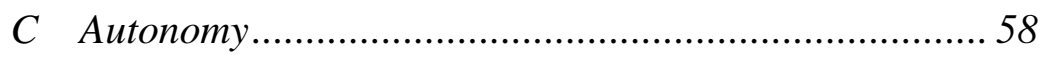

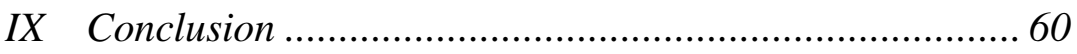

X Bibliography..........................................................ii 
For if we would judge ourselves, we should not be judged. ${ }^{1}$

The first impulse of a rudimentary soul is to do justice by his own hand. Only at the cost of mighty historical efforts has it been possible to supplant in the human soul the idea of justice entrusted to authorities. ${ }^{2}$

\section{Introduction}

1 In recent speeches international arbitration expert Gary Born proposed bilateral arbitration treaties ("BATs") — arrangements between states that would establish a default regime whereby commercial contracts between parties of each State would by default be submitted to arbitration. ${ }^{3}$ International commercial arbitration is not a new phenomenon, and nor is pro-arbitration State policy. ${ }^{4}$ What is novel about the BAT is the expansive abandonment of State sovereignty in favour of private organisations, and the departure from the principle that arbitration is based on express consent. ${ }^{5}$

2 The usefulness and legality of a BAT in New Zealand has been the subject of recent commentary. ${ }^{6}$ Ideally, the BAT would work to reduce transaction costs by alleviating concerns enterprises might have about undertaking trade in foreign jurisdictions. Disputes arising from international transactions

${ }^{1} 1$ Corinthians 11:31, Authorised (King James) Version.

2 Eduardo J Couture "The Nature of the Judicial Process" (1950) 25 Tulane Law Review 1 at 7.

3 See, for the text of the speech, Gary Born "BITs, BATs and Buts: Reflections on International Dispute Resolution" (2014) 13 YAR.

${ }^{4}$ See Gary Born International Commercial Arbitration: Volume I (2nd ed, Kluwer International Law, 2014) at 1326; William W Park Arbitration of International Business Disputes: Studies in Law and Practice (2nd ed, Oxford University Press, New York, 2012) at 215; Mitsubishi Motors Corp v Soler Chrysler-Plymouth Inc 473 US 614 (1985); Fiona Trust \& Holding Corp v Privalov [2007] 1 All ER (Comm) 891.

5 See generally Andrea Marco Steingruber Consent in International Arbitration (Oxford University Press, New York, 2012).

${ }^{6}$ Petra Butler and Campbell Herbert "Access to Justice vs Access to Justice for Small and Medium Enterprises: The Case for a Bilateral Arbitration Treaty" (2014) NZJPIL (forthcoming). 
can be exceptionally expensive and time-consuming to resolve due to the layering of counsel across jurisdictions and the need for specialist advice. ${ }^{7}$ It is possible, then, that the BAT would reduce the costs of disputes that emerge where the parties have omitted to opt for arbitration in circumstances where it would have been efficient for them to have done so. Born argues: ${ }^{8}$

If you provide a more effective means of dispute resolution for international transactions you will get more international transactions.

3 This paper, however, focusses on the constitutional significance of a regime that, by default, places international commercial disputes outside the reach of the State courts. While this paper principally concerns the New Zealand constitution, it draws on international materials and seeks to illustrate more general points common to many domestic legal systems.

4 In Part II the paper provides an overview of the provisions and general effect of the BAT. To introduce the way this paper uses the concept of 'constitutionality', Part III develops a definition of the term, explains the paper's methodology, and introduces some broad constitutional principles.

5 The balance of the paper develops these constitutional principles and measures the BAT against them. Part IV examines the BAT in light of the New Zealand Bill of Rights Act 1990 (BORA), concluding that, while the BAT is not unjustifiably inconsistent with the BORA, the Act might speak to broader constitutional principles that are nonetheless salient. The principle of the separation of powers is discussed in Part $\mathrm{V}$, which concludes that the BAT is a significant interference with the judiciary's traditional domain and the institutional balance of State powers which is the purpose of that principle. Part VI considers whether the BAT is consistent with the principle of the rule of law, and in Part VII it is argued that the BAT amounts to an unconstitutional privatisation of a core State function - the administration of justice. Finally, Part VIII

\footnotetext{
${ }^{7}$ Butler and Herbert, above n 6, (forthcoming).

8 Tom Moore "Born's BAT gets set to fly" (2 January 2014) Commercial Dispute Resolution News <www.cdr-news.com>.
} 
suggests that the BAT may be inconsistent with New Zealand's central constitutional principle: representative democracy.

6 Genn observed that the role of the civil justice system "provides the legal structure for the economy to operate effectively and for the power of government to be scrutinised and limited." It will be argued that the BAT makes a tension of these two ends. Its purpose is to improve economic efficiency, but it achieves that at the expense of thorough scrutiny of government action. For that reason, it may not be constitutional.

\section{Overview of the BAT}

7 This part examines the effect that the BAT purports to have, and the legal mechanisms by which those effects would be achieved. This is of significance to the question of the constitutionality of the BAT because the institutions responsible for its effect, and the means by which it takes effect, will be important to understanding its constitutional import.

8 The BAT can be conceived of as either being a form of sui generis State-mandated dispute resolution, or as a form of international commercial arbitration. ${ }^{10}$ In the former case, the BAT, and the legal structure it creates, can be seen as the State establishing the arbitral tribunal as a court or a decision-maker, in the same way that it has done in relation to other disputes. ${ }^{11}$ Accordingly, the power of the tribunal when it is established for a BAT arbitration flows from the power of the State. ${ }^{12}$ Under the alternative conception, the State may be more simply creating a standard implied term in international commercial contracts.

\footnotetext{
9 Hazel Genn Judging Civil Justice (Cambridge University Press, Cambridge, 2010) at 16.

${ }^{10}$ See Butler and Herbert, above n 6, (forthcoming).

11 The High Court is, roughly speaking, the only court of inherent jurisdiction. All others exercise statutory jurisdiction. See further below at [114].

${ }^{12}$ In this respect, the theoretical underpinning of BAT arbitration would diverge from received understandings of the juridical rationale for the authority of arbitral tribunals. See generally Emmanuel Gaillard Legal Theory of International Arbitration (Martinus Nijhoff Publishers, The Netherlands, 2010).
} 
9 Determining which conception best accords with the character of the BAT is significant for its interaction with the constitution. In some sense, though, each conception is in substance the establishment of private tribunals as the default mechanism for the resolution of particular disputes. The difference would really lie only in the terms with which we would describe the legal effect of the BAT, be it those of public or private law; the arrangement of the courts, or the default terms of commercial contracts.

10 Whether a mechanism of dispute resolution can properly be termed arbitration depends on the presence of features characteristic of arbitration. ${ }^{13}$ The BAT is, in the author's view, best understood as a State-established form of dispute resolution that seeks to use the existing mechanism of international commercial arbitration.

11 The language of the BAT suggests, though, the view that the form of dispute resolution is in fact arbitration. The process is described as arbitration throughout, and the BAT seeks to harness the existing mechanisms that facilitate arbitration, such as the New York Convention, the UNCITRAL Arbitration Rules, and the Permanent Court of Arbitration. The effect, however, is to grant what appears to be an arbitral tribunal the powers otherwise reserved to State courts exercising jurisdiction by sovereign right. Accordingly, this paper will use the language of public and constitutional law to analyse the BAT. $^{14}$

12 This sub-part provides an overview of how the BAT would function, so far as is relevant to assessing its constitutional compliance. This assessment is based on the draft BAT produced by Gary Born. ${ }^{15}$

\footnotetext{
${ }^{13}$ David A R Williams and Amokura Kawharu Williams \& Kawharu on Arbitration (LexisNexis, Wellington, 2011) at 4.

${ }^{14}$ An analysis of the BAT from a private law perspective would, though, be fruitful. Possible areas of further enquiry are the consistency of the implied term conception of the BAT with principles of contract law. See on that topic generally Randy E Barnett "The Sound of Silence: Default Rules and Contractual Consent" (1992) 78 Virginia Law Review 886.

${ }^{15}$ See appended copy.
} 


\section{A Functional effect of the BAT}

\section{General provisions}

13 The BAT would be a treaty between two States. Legal persons organised for profit in each jurisdiction would be "enterprises" for the purposes of the treaty. ${ }^{16}$ A controversy between enterprises in relevant jurisdictions arising out of inter alia a commercial contract would be designated an "International Commercial Dispute". ${ }^{17}$ Where an International Commercial Dispute exists between parties, by service of notice one party may propose good faith discussions to be concluded within 30 days. ${ }^{18}$ If the period concludes without amicable resolution, the party may issue a notice of arbitration and refer the dispute to arbitration. ${ }^{19}$ The effect is, or purports to be, the same as that of an arbitration agreement to which the parties expressly consented.

14 Parties would be free to opt-out of the default regime by selecting an alternative arbitration procedure ${ }^{20}$ choosing a State-based forum or an alternative dispute resolution mechanism such as expert determination, ${ }^{21}$ or by simple agreement that the BAT would not be applicable to the contract. $^{22}$

15 If the contract did not by express writing do one of the above, the contract would be subject to the default provisions of the BAT. ${ }^{23}$ The default mechanism would provide for matters that would ordinarily be the features of an arbitration agreement. The Permanent Court of Arbitration is to appoint arbitrators,

\footnotetext{
${ }^{16}$ Draft BAT, art 1.

${ }^{17}$ Draft BAT, art 1 . Note that the Draft BAT excludes from the definition of an International Commercial Dispute consumer disputes, employment or labor disputes, domestic relations disputes, marital or child custody disputes, and inheritance disputes. State parties could further tailor that list to comport with their public policy positions on what matters ought not to be arbitrable (or, not, at least, without positive consent).

${ }^{18}$ Draft BAT, art 2(1)(a).

${ }^{19}$ Draft BAT, art 2(1)(b).

${ }^{20}$ Draft BAT, art 5(1)(b).

${ }^{21}$ Draft BAT, art 5(1)(c) and (d).

${ }^{22}$ Draft BAT, art 5(1)(a).

${ }^{23}$ Draft BAT, art 4(1).
} 
and the arbitration is to be subject to the UNCITRAL Arbitration Rules. $^{24}$

\section{Role of State courts}

16 Courts in the States party to the treaty would be obliged, where there existed an International Commercial Dispute, to refer the parties to arbitration, upon request of one of the parties. ${ }^{25}$ Where a court finds a binding arbitration agreement, there exists a duty not to litigate. That duty is given effect by Art 8 of the Model Law, or art 8, sch 1 of the Arbitration Act 1996, each of which oblige courts to stay litigation in breach of an arbitration agreement. ${ }^{26}$ Where a party seeks litigation in a foreign jurisdiction in breach of the arbitration agreement, an anti-suit injunction may be available. ${ }^{27}$

\section{Status of awards}

17 The BAT purports to designate awards made by tribunals operating under a jurisdiction born of the treaty as "awards.", 28 It achieves this by indicating the "mutual desire and expectation" of the State parties to the BAT that awards made under it are enforceable under the New York Convention, and that the provisions of the BAT be "deemed to constitute a valid agreement to arbitrate" between the relevant enterprises subject to the BAT. ${ }^{29}$

18 This is significant, in that in foreshadows a possible reluctance on part of some State courts to enforce arbitral awards in absence of consent to arbitration, notwithstanding 'proarbitration' interpretative presumptions. ${ }^{30}$

\footnotetext{
${ }^{24}$ Draft BAT, art 4(1).

25 Draft BAT, art 3(1). The use of the term request suggests that with acquiescence of both parties, a dispute could be determined in a State court, notwithstanding its status as an International Commercial Dispute for the purposes of the BAT.

${ }^{26}$ Williams and Kawharu, above n 13, at 96.

27 Williams and Kawharu, above n 13, at 78. See also concerning general jurisdiction to regulate proceedings in relation to arbitration Carter Holt Harvey Ltd v Genesis Power Ltd [2006] 3 NZLR 794 (HC) at [61].

${ }^{28}$ Draft BAT, art 6.

${ }^{29}$ Draft BAT, art 6(4).

30 See, concerning this interpretative approach, See Born International Commercial Arbitration: Volume I, above n 4, at 1326; Park, above n 4, at 215; Mitsubishi Motors Corp v Soler Chrysler-Plymouth Inc 473 US 614
} 


\section{Confidentiality}

19 Arbitrations under the BAT will be entirely confidential unless the parties expressly in writing agree otherwise. Parties would be required to keep confidential "all materials submitted in or created for the purpose of the arbitration, all documents produced by another party in the arbitration not otherwise in the public domain, and all awards, orders and other communications in the arbitration". ${ }^{31}$ The provision allows an exception, though, where disclosure is necessary for proceedings in court related to, for example, the enforcement of an award.

20 It would of course be open to the State parties to modify the BAT to suit their needs, and remove the confidentiality provision. It is not an essential feature of the scheme, but rather reflects the general practice of confidentiality in international arbitration. ${ }^{32}$ This paper proceeds on the basis that State parties would adopt the BAT from the draft as it stands, but acknowledges that some of the criticisms leveled at the BAT could be mitigated with minor modifications. Confidentiality is one of these areas. ${ }^{33}$

\section{B Conformity with New Zealand arbitration law}

21 The BAT is designed to fit in with the existing legislation that enables the operation of arbitration. In New Zealand, the relevant legislation is the local enactment of the Model Law, that being the Arbitration Act 1996. The Act provides a definition of an arbitration agreement: ${ }^{34}$

... an agreement by the parties to submit to arbitration all or certain dispute which have arisen or which may arise between them in respect of a defined legal relationship, whether contractual or not ...

(1985); Fiona Trust \& Holding Corp v Privalov [2007] 1 All ER (Comm) 891.

${ }^{31}$ Draft BAT, art 4(2).

32 Gary Born International Commercial Arbitration (Kluwer Law International, The Netherlands, 2009) at 87.

${ }^{33}$ See below at Part VIII.

${ }^{34}$ Arbitration Act 1996, s 2. 
22 The law accordingly requires consent to arbitration. Consent is generally found in the form of the arbitration agreement, ${ }^{35}$ except inter alia in cases where non-signatories are bound by the agreement. ${ }^{36}$

23 Some other dispute resolution mechanisms referred to as "arbitration" may lack a consensual basis. Compulsory schemes of industrial arbitration have historically existed in New Zealand, and continue to operate in Australia. ${ }^{37}$ Similarly, it has been suggested that investor-State dispute resolution is an example of non-consensual arbitration for the reason that there is no privity between the relevant State and investor. ${ }^{38}$ This is not, however, the case: consent is manifested in these circumstances in the State's standing offer to arbitrate. ${ }^{39}$

24 The Law Commission has observed that statutorily imposed arbitration may have real practical benefit, even in absence of an agreement to arbitrate. ${ }^{40}$ Accordingly, s 9 of the Arbitration Act 1996 allows that Act to yield to another where there exists an inconsistency.

25 Indeed, the Law Commission recommended that the High Court Rules be amended to allow for the Court to refer a dispute to a referee, ${ }^{41}$ despite the inclusion of court-ordered arbitration being rejected from inclusion in the Arbitration Act 1996 on the grounds that it was inappropriate for a scheme based on consent. ${ }^{42}$

26 The centrality of consent to the statutory language would require that domestic law be modified to accommodate the BAT.

\footnotetext{
${ }^{35}$ Williams and Kawharu, above n 13, at 4.

${ }^{36}$ See generally, Williams and Kawharu, above n 13, at [4.7].

${ }^{37}$ Industrial Conciliation and Arbitration Act 1894, the Industrial Relations Act 1973, and the Industrial Relations Amendment Act 1977, and Fair Work Act 2009 (Cth). See Butler and Herbert, above n 6, (forthcoming).

${ }^{38}$ This argument features in Butler and Herbert, above n 6, (forthcoming).

${ }^{39}$ Williams and Kawharu, above n 13, at 15. Written consent is said to exist in the form of the treaty: Campbell McLachlan, Laurence Shore and Matthew Weiniger International Investment Arbitration: Substantive Principles (Oxford University Press, Oxford, 2008) at [3.28] and [4.60]. See also Jan Paulsson The Idea of Arbitration (Oxford University Press, Oxford, 2013) at 53.

${ }^{40}$ Law Commission Arbitration (NZLC R20, 1991) at [115].

${ }^{41}$ At [109]-[110].

${ }^{42}$ Williams and Kawharu, above n 13, at 16.
} 


\section{Opportunities for review}

27 This section sets out the legal framework for review of arbitral awards. ${ }^{43}$ The basis for review of an arbitral awards in New Zealand is now in conformity with the scope of review under the Convention on the Recognition and Enforcement of Foreign Arbitral Awards ("New York Convention"). ${ }^{44}$ The grounds of the New York Convention are codified in the Arbtration Act $1996 .{ }^{45}$

28 The Arbitration Act 1996 further provides for appeals on matters of law. But, for those provisions to apply, parties subject to an international arbitration must expressly contract to that effect. ${ }^{46}$ Accordingly, it is not conceivable that such review will be available subsequent to BAT arbitration, unless it is the case that the parties, by consent, opt to modify the default operation of the BAT. ${ }^{47}$

\section{Summary}

While the BAT purports to refer disputes to arbitration, it is, in the author's view, better characterised as a system of Stateestablished private dispute resolution which uses the mechanism of arbitration to administer justice. This characterisation provides, then, a starting point for addressing the central concern of this paper: is such a system constitutional?

\section{What is meant by "constitutionality"}

30 For the purposes of this paper, it is necessary to briefly examine the meaning of the phrase "constitutional" in the New Zealand context. This part will examine the definition of constitutional law, the methodology adopted for identifying

\footnotetext{
${ }^{43}$ The scope of review is addressed in more detail below at [56] et seq.

${ }^{44}$ Convention on the Recognition and Enforcement of Foreign Arbitral Awards 330 UNTS 3 (opened for signature 10 June 1958, entered into force 7 June 1959). Williams and Kawharu, above n 13, at 40 and 467.

${ }^{45}$ Arbitration Act 1996, sch 2 cl 5(8), and sch 1 art 34(3) and (4). I use review to encompass both the setting aside of an award at the seat, and the process by which the enforcement of an award is challenged.

${ }^{46}$ Arbitration Act 1996, s 6 and sch 2, cl 5. See Williams and Kawharu, above $\mathrm{n} 13$, at 43 .

${ }^{47}$ This appears to be permitted by the Draft BAT: see art 5(3).
} 
New Zealand's constitution, and provide a brief overview of core constitutional principles which will be the subject of more detailed treatment in later parts.

31 A constitutional law is one that pertains to the "distribution and allocation of public authority". ${ }^{48}$ Or, as Edlin would have it, a matter is constitutional where it involves: ${ }^{49}$

substantive feature of government authorityexpressed in terms of the institutional allocation of authority or the articulation of fundamental rights and liberties - and a possible modification, disruption or abrogation of fundamental rights or institutional authorities.

32 Definitions aside, determining quite what amounts to a constitutional law, convention or principle presents some difficulty. Elias CJ observed that the constitution is a "subject in constant motion", and "not easily explained." 50

33 The locations of constitutional law are many: statutes, common law, the Standing Orders of the House of Representatives, Te Tiriti o Waitangi, the Cabinet Manual, the practice of public office holders, et cetera. ${ }^{51}$ Properly extra-legal sources, such as political philosophy, may also be influential. ${ }^{52}$ The difficult to describe "constitutional culture built on shared principles" also affects the observance and development of the constitution and must feature in an analysis of what is constitutional. ${ }^{53}$

34 Accordingly, in attempting to discern the shape of the New Zealand constitution, this paper relies on a range of sources, none of which is authoritative. I adopt an approach based on the science of law as articulated by HLA Hart in The Concept of Law. Briefly, what is law is to be determined by the rule of

48 S E Finer, Vernon Bogdanor and Bernard Rudden Comparing Constitutions (Oxford University Press, Oxford, 1995) at 85.

${ }^{49}$ Douglas E Edlin "A Constitutional Right to Judicial Review: Access to Courts and Ouster Clauses in England and the United States" (2009) 57 The American Journal of Comparative Law 67 at 73. See similarly Cabinet Office Cabinet Manual 2008 at "Introduction".

50 Sian Elias "Fundamentals: A Constitutional Conversation" (2011) 19 Waikato Law Review: Taumauri 1 at 1.

${ }^{51}$ See generally Philip A Joseph Constitutional and Administrative Law in New Zealand (4th ed, Brookers, Wellington, 2014) at ch 2.

${ }_{52}^{5}$ Elias, above n 50, at 5.

53 At 6. See generally Matthew Palmer "New Zealand Constitutional Culture" (2007) 22 NZULR 565. 
recognition in a particular legal system. ${ }^{54}$ The practice that constitutes the rule of recognition is that of senior legal officials. ${ }^{55}$ Their conduct and consensus reveals whether a particular rule amounts to a law, convention, or principle. Canvassing a range of expressions of opinion on part of different constitutional actors should provide a rough sense of the constitutional implications of the BAT. There are, however, limitations to this methodology.

35 A particular challenge in describing the constitution is that it in part relies on the concept of a "collaborative enterprise" of reciprocity between the branches of government. ${ }^{56}$ This relationship is sometimes termed 'comity'. This mode of constitutional development relies on dialogue between constitutional actors, which necessarily takes place over a period of time. The answer to what is constitutional, then, can sometimes only emerge when the particular issue is raised. The constitution is in 'constant motion'. We can predict what constitutional actors will consider within the bounds of what is constitutional, but it will be speculative.

Most cynically, a realist criticism would argue that the New Zealand constitution - and perhaps any constitution ${ }^{57}$ — is really a matter of "what happens" over time. ${ }^{58}$ But the normative content of this paper, and the sources on which it relies, is still of use even accepting ardent realism. 'What happens' is a result of the actions of constitutional actors; actions which are constrained by the constitution so far as the relevant actor considers itself bound by a particular norm. Accordingly, Palmer contends that the "symbolic and normative power of a constitution derives from the continued adherence to its

\footnotetext{
${ }^{54}$ HLA Hart The Concept of Law (Oxford University Press, Oxford, 1961) at $92-120$.

${ }_{55}^{55}$ At 104.

${ }^{56}$ Joseph, above n 51, at 2, see further at 574, fn 459 .

${ }^{57}$ John Priestley "Chipping Away at the Judicial Arm?" (2009) 17 Waikato Law Review: Taumauri 1 at 7.

${ }^{58}$ Peter Hennessy Cabinet (Basil Blackwell, Oxford, 1986) at 80, cited in Matthew Palmer "Legislative Constitutionalism Ascendant? Who Interprets an Unwritten Constitution in New Zealand?" (paper presented to Conference on Legislatures and Constitutionalism: The Role of Legislatures in the Constitutional State, Centre for Constitutional Studies, Alberta, July 2004).
} 
evolving content by those it governs." 59 So we are back where we started: what are those norms, and what is the normative hold they have over constitutional actors?

37 Assessing the constitutionality of the BAT presents unique difficulties. The policy is, in the author's view, novel and not easily compared to other policies in New Zealand history. ${ }^{60}$ Accordingly, the already murky waters of constitutional law become even more opaque where the BAT is concerned-no extant expressions of opinion on constitutional law will directly confront the issues the BAT presents. As a consequence, this paper must at times work by way of analogy, a challenging mode of reasoning in the best of situations, and one that is more difficult here because the role of the judiciary is undertheorised in New Zealand scholarship. ${ }^{61}$ For this reason, some sources are quoted at length. The author must rely on his own sense of the meaning of the various sources, extrapolating from their general terms more specific meanings that will be useful for assessing the BAT. But, given the contentious nature of the subject matter, he wishes to afford the reader the opportunity to see for him or herself whether the sources support the author's thesis.

38 This paper concerns what will be done about the BAT, as well as what ought to be done about a BAT from a constitutional perspective. The next questions, then, are what is the content of the constitution (the $i s$ ), and what should we do when faced with a policy that challenges the content of the constitution (the ought).

59 Matthew Palmer "Legislative Constitutionalism Ascendant? Who Interprets an Unwritten Constitution in New Zealand?" (paper presented to Conference on Legislatures and Constitutionalism: The Role of Legislatures in the Constitutional State, Centre for Constitutional Studies, Alberta, July 2004).

${ }^{60}$ But see Law Commission, above n 40, at ch 10. Those examples, however, involved much greater judicial supervision and control than the BAT affords.

${ }^{61}$ Or, as Palmer expresses the same sentiment, there may be a concern "about how deeply [the public's] acceptance and respect [for the judiciary] is rooted in our constitutional culture": Matthew Palmer "The Place of the Judiciary in the Constitutional Culture of New Zealand" (Paper presented to the Symposium on Australasian Constitutionalism, Centre for Comparative Constitutional Studies, University of Melbourne Law School, December 2013) at 1 . See, concerning the absence of discussion of courts in positivist jurisprudence, Jeremy Waldron "The Concept and the Rule of Law" (Working Paper No. 08-50, Public Law \& Legal Theory Research Paper Series, New York University School of Law) at 20. 
39 The starting point for assessing the constitutionality of the BAT is to determine the content of the constitution. It hardly bears repetition, but New Zealand has no supreme law ${ }^{62}$ and Parliament has plenary power to make law. ${ }^{63}$ But beneath those basic observations, there are more sophisticated structures. The constitutional principles that this paper will focus on are the separation of powers, ${ }^{64}$ the rule of law, ${ }^{65}$ and representative democracy. ${ }^{66}$

40 Some of these principles are more central to the constitution than others. Or, in other words, the polity has a preference for particular approaches to defining and regulating State power. So, for example, Palmer points out that the solution to discontent with the power of the legislature under the first-pastthe-post electoral system was "found in the primary constitutional norm - representative democracy - rather than the US style separation of powers by placing trust in the independent, and unelected, judiciary." ${ }^{\prime 67}$ That is, a preference for reliance on representative democracy, rather than the rule of law and separation of powers. Simiarly, the public has generally not supported moves to increase the power of the judiciary relative to the legislature. ${ }^{68}$

41 So the constitutional principles discussed will bear more or less on the BAT — or any other policy decision — according to their importance. While that might at first seem prosaic, it is an important observation. Not all of the issues discussed in the paper are of equivalent weight - the strength of particular principles wax and wane over time.

\footnotetext{
${ }^{62}$ Consider New Zealand Bill of Rights Act 1990, s 4.

${ }^{63}$ See Supreme Court Act 2003, s 3(2), which reads: "Nothing in this Act affects New Zealand's continuing commitment to the rule of law and the sovereignty of Parliament." See also Constitution Act 1986, s15(1), which reads: "The Parliament of New Zealand continues to have full power to make laws."

${ }^{64}$ Joseph, above n 51, at [1.6.4].

${ }^{65}$ At ch 7.

${ }^{66}$ At [1.6.2] and ch 8 .

${ }^{67}$ Palmer, above $\mathrm{n} 61$, at 8 .

${ }^{68}$ At 23.
} 


\section{$B$ The 'ought' of the constitution}

42 With a constitution as flexible as New Zealand's, departure from the rules can prompt one of two outcomes. The country could experience a constitutional crisis, or the constitution could change to reflect the incorporation of the circumstances into the constitution. The former is not a necessary prerequisite for the latter - the constitution may change without crisis. ${ }^{69}$ But the former is likely to bring about the latter. Crisis or change may come about when one constitutional actor asserts a particular power and other constitutional actors either object or tolerate the assertion. ${ }^{70}$

43 The constitutional actors that would be responsible for implementing the BAT would be the executive and Parliament. It would be an international agreement between New Zealand and another State. In New Zealand, international agreements are a product of joint executive and legislative action. ${ }^{71}$ These actors have a central role in creating and enforcing constitutional rules, particularly so because the executive and Parliament are far and away the more powerful branches of government, and the judicial "the junior and least powerful of the working parts of the constitution."72

44 The case this paper makes is, then, directed at legislators and policy makers. And when it proposes that a particular thing is constitutional, or unconstitutional, what is really being said is this: "for the reason of the constitution, you should(n't) pursue this policy." The claim is as political as it is legal in that the constitutional law concerns the allocation of political authority.

45 The reason that such actors should pay attention to these kind of arguments is that, in broad terms, "those who [are] in a position to modify the law have a responsibility to arrive at a sound view about what makes a legal change a good change or

\footnotetext{
${ }^{69}$ See, for some illustrative examples, Palmer, above n 53, at 593.

${ }^{70}$ Consider Fitzgerald v Muldoon [1976] 2 NZLR 615 (SC).

${ }^{71}$ Geoffrey Palmer and Matthew Palmer Bridled Power: New Zealand's Constitution and Government (4th ed, Oxford University Press, Melbourne, 2004) at 357; Joseph, above n 51, at [11.7.6].

${ }^{72}$ Elias, above n 50, at 8.
} 
a bad change." ${ }^{73}$ Any derogation from a constitutional principle such as the rule of law "calls for close consideration and clear justification." ${ }^{74}$ More specifically, when it comes to developing policy, or legislating, the legislature ought to pay attention to: ${ }^{75}$

not just $\ldots$ the particular measure under consideration but also to the way in which that measure will affect the broad impact of the legal system on the interests and rights of citizens.

Palmer suggests that one of the drawbacks of the 'unwritten' constitution is that "it is easier for those elements to change, and for some groups of people to consciously change them, without serious public discussion, or even awareness, that a change is contemplated." 76 The need for careful consideration of the effect of a policy as radical as the BAT is all the more acute, then, in the New Zealand context.

\section{Compatibility with the New Zealand Bill of Rights Act}

47 The BORA applies to acts of the "legislative, executive, or judicial branches of the Government of New Zealand", as well as "any person or body in the performance of any public function, power, or duty conferred or imposed on that person or body by or pursuant to law.",77

The BORA would be engaged by the BAT in three main ways. Firstly, it would control the legislative decision to enact legislation to implement the treaty in that it contains a direction "to those enacting or prescribing limits" to not unjustifiably infringe the protected rights. ${ }^{78}$ It would also apply to the interpretative actions of the courts when determining, for example, whether awards made under non-consensual arbitration pursuant to the BAT were properly within the meaning of "award" for the purposes of the existing

\footnotetext{
73 Jeremy Waldron "Principles of Legislation" in Richard W Bauman and Tsvi Kahana (eds) The Least Examined Branch: The Role of the Legislature in the Constitutional State (Cambridge University Press, 2006) 15 at 23.

${ }^{74}$ Lord Bingham "The Rule of Law" (2007) 66 CLJ 67 at 69.

${ }^{75}$ Waldron, above $\mathrm{n} 73$, at 24.

${ }^{76}$ Palmer, above in 53, at 593.

${ }^{77}$ New Zealand Bill of Rights Act 1990, s 3.

${ }^{78}$ Hansen v R [2007] NZSC 7, [2007] 3 NZLR 1 at [15], per Elias CJ.
} 
enforcement regime, or indeed in any relevant interpretation. ${ }^{79}$ Finally, it may have implications for the operation of the arbitral tribunal itself, so far as it can be characterised as performing a "public function, power, or duty" that has been "conferred ... on ... [it] by or pursuant to law." 80

49 The rights and freedoms guaranteed in the BORA apply to juridical as well as natural persons, so far as practicable. ${ }^{81}$ The BAT applies, per art 1 of the draft, to "enterprises" where an enterprise is a "legal or juridical entity constituted or organized for profit." Accordingly, so far as the BAT places limitations on the rights of enterprises, BORA is engaged.

\section{A Natural justice}

50 The BAT, by requiring parties to go to arbitration, intends to circumscribe access to the courts. This presents a potential infringement of s 27(1) of the BORA, which guarantees the observance of principles of natural justice:

\section{Right to justice}

(1) Every person has the right to the observance of the principles of natural justice by any tribunal or other public authority which has the power to make a determination in respect of that person's rights, obligations, or interests protected or recognised by law.

51 An arbitral tribunal pursuant to the BAT would constitute a "tribunal" within the meaning of s 27. Case law indicates that the word 'tribunal' requires a broad interpretation, ${ }^{82}$ and that 'determination' has an "adjudicative sense". ${ }^{83}$ This interpretation is consistent with the case law of the United

\footnotetext{
${ }^{79}$ Andrew Butler and Petra Butler The New Zealand Bill of Rights Act: A Commentary (LexisNexis, Wellington, 2005) at [5.6.5].

${ }^{80}$ See further below at [107] et seq.

${ }^{81}$ Section 29. See generally Butler and Butler, above $\mathrm{n} 79$, at [5.11].

${ }^{82}$ Ministry of Transport $v$ Noort [1992] 3 NZLR 260 (CA) at 278. See also Paul Rishworth et al The New Zealand Bill of Rights (Oxford University Press, Auckland, 2003) at 754, 755; Taito $v R$ [2003] 3 NZLR 577 (PC) at [20].

${ }_{83}$ Chisholm v Auckland City Council (CA 32/02, 29 November 2002); Butler and Butler, above n 79, at [25.2.19].
} 
Kingdom that found an arbitration to have quasi-judicial functions. ${ }^{84}$

52 The meaning of natural justice has "not been the subject of any sustained judicial analysis." ${ }^{\circ 5}$ The courts have found violations of natural justices where: a party was not allowed the opportunity to appear; ${ }^{86}$ a party was not adequately notified of elements of the proceedings, ${ }^{87}$ there were substantial delays in making a determination. ${ }^{88}$ The strictness of natural justice requirements are concomitant with the significance of the decision at hand. ${ }^{89}$

53 Importantly for the compliance of the BAT and attendant procedural rules, the view that the concept of natural justice in s 27 goes beyond procedural guarantees and protects substantive interests has not taken hold. ${ }^{90}$ Natural justice is focussed on procedure and process. ${ }^{91}$

54 The procedural controls provided by the BAT are compliant with the requirements of natural justice. ${ }^{92}$ There is no apparent infringement of BORA in this respect. This should not, though, be surprising. Institutional arbitration rules operative in a competitive environment and to secure participation from

\footnotetext{
${ }^{84}$ Jivraj v Hashwani [2011] WLR 1872; [2011] UKSC 40 (SC) at [41] per Clarke LJ.

${ }^{85}$ Butler and Butler, above n 79, at [25.2.4].

${ }^{86}$ Matthews v Marlborough District Council [2000] NZRMA 451 (HC) (substantial costs fixed without opportunity for submissions from unsuccessful party); Pomeroy v Police [2000] NZAR 273, (1999) 5 HRNZ 405 (HC) (defendant unable to access court due to disability).

${ }^{87}$ Police v Sharmly (No 1) [1999] DCR 1186 (DC) (failure to notify accused of evidence in time to prepare defence); Lal v Removal Review Authority HC Wellington AP95/92, 10 March 1994 (failure to inform applicant of important omission in application).

88 Unitech University of Technology v Attorney-General HC Wellington CIV 2005-485-89, 7 July 2005 (two year delay in processing application for accreditation as a university).

${ }^{89}$ Ali v Deportation Review Tribunal [1997] NZAR 208 (HC) at 220 per Elias J; Geoffrey Palmer "A Bill of Rights for New Zealand: A White Paper" [1984-1985] I AJHR A6 at [10.168].

${ }^{90}$ Westco Lagan v Attorney-General [2001] 1 NZLR 40 (HC) at [60]-[61].

${ }^{91}$ Butler and Butler, above n 79, at [25.2.14]. See further Ministry of Justice The Guidelines on the New Zealand Bill of Rights Act 1990: A Guide to the Rights and Freedoms in the Bill of Rights Act for the Public Sector <www.justice.govt.nz> at s 27.

${ }^{92}$ See Butler and Herbert, above n 6, (forthcoming).
} 
consenting commercial parties must be able to at least appear to provide for natural justice. ${ }^{93}$

55 In any event, for a party based in New Zealand that is having an award enforced against it, a breach of natural justice is an explicit grounds on which a court may refuse to enforce an award. ${ }^{94}$ The courts have observed in respect of domestic arbitration that it is a procedure with "enforceable standards of natural justice," 95 and the courts may refuse to enforce an award on those grounds.

\section{B Judicial review}

Section 27(2) guarantees access to judicial review of determinations of tribunals and public authorities concerning rights, obligations and interests.

\section{Right to justice}

(2) Every person whose rights, obligations, or interests protected or recognised by law have been affected by a determination of any tribunal or other public authority has the right to apply, in accordance with law, for judicial review of that determination.

57 The phrase 'judicial review' is not used in any technical sense, ${ }^{96}$ and the provision should be interpreted generously. ${ }^{97}$ In Mangawhai Ratepayers' and Residents' Association Inc $v$ Kaipara District Council, 27(2) was described as protecting "access to justice": 98
a person's access to the Courts to challenge the legality of public decision-making is a fundamental right designed to guard against the abuse of public power.

\footnotetext{
${ }^{93}$ See Bryan Caplan and Edward P Stringham "Privatising the Adjudication of Disputes" (2008) 9 Theoretical Enquiries in Law 503 at 517; Peter B Rutledge Arbitration and the Constitution (Cambridge University Press, New York, 2013) at 151. But see discussion below at [179].

${ }^{94}$ Arbitration Act 1996, sch 1 art 36(3).

95 Methanex Motunui Ltd v Spellman [2004] NZLR 95 (HC) at [50].

${ }^{96}$ Burt v Govenor-General [1992] 3 NZLR 672 (CA) at 679, per Cooke P.

${ }^{97}$ Ministry of Transport $v$ Noort [1992] 3 NZLR 260 (CA).

98 Mangawhai Ratepayers' and Residents' Association Inc $v$ Kaipara District Council [2014] NZHC 1147 at [92].
} 
58 Others doubt that the right necessarily entails grounds for appeal. ${ }^{99}$ The provision has a wide effect, limiting the legislature's ability to oust judicial review. ${ }^{100}$ The White Paper suggests that s 27(2) of the BORA "sets out and gives enhanced status to the basic constitutional right to go to court to challenge the legal validity of government actions."101 Similarly, it would serve as a check on privative clauses that purport to restrict judicial review. ${ }^{102}$

59 The Draft BAT confines rights of judicial review in a manner identical to the limitations under the New York convention. ${ }^{103}$ Accordingly, it coheres with the framework for review provided by the Arbitration Act $1996 .{ }^{104}$

60 Broadly, the grounds of available review most relevant to the BAT are: lack of notice or lack of opportunity to present case ${ }^{105}$ excess of jurisdiction; ${ }^{106}$ or that the dispute is not capable of settlement by arbitration or enforcement of the award would be contrary to public policy. ${ }^{107}$

61 While the New York Convention does not go so far as to define public policy reasons for denying enforcement of an award, the Arbitration Act 1996 clarifies the term (though does not limit it). An award is contrary to public policy where: ${ }^{108}$

(a) the making of the award was induced or affected by fraud or corruption; or

(b) a breach of the rules of natural justice occurred-

(i) during the arbitral proceedings; or

\footnotetext{
99 Butler and Butler, above n 79, at [25.3.14]. Appeal and review may, though, be distinguished: Joseph, above n 51, at [22.2.3]

100 See Zaoui v Attorney-General (No 2) [2005] 1 NZLR 690 (CA), where the Court found that review had not been inferentially ousted. See Butler and Butler, above n 79, at [25.3.20].

${ }^{101}$ Palmer "A White Paper", above n 89, at [10.127].

102 At [10.127].

103 Compare Draft BAT, art 7 and Convention on the Recognition and Enforcement of Foreign Arbitral Awards 330 UNTS 3 (opened for signature 10 June 1958, entered into force 7 June 1959), art V.

${ }^{104}$ See above at [27]-[28].

105 Arbitration Act 1996, sch 1 art 36(1)(a)(ii).

${ }^{106}$ Arbitration Act 1996, sch 1 art 36(1)(a)(iii).

107 Arbitration Act 1996, sch 1 art 36(1)(b).

108 Arbitration Act 1996, sch 1 art 36(3).
} 
(ii) in connection with the making of the award.

62 While this codification is relatively unusual, ${ }^{109}$ a similar narrow approach to the interpretation of the public policy exception is preponderant internationally. ${ }^{110}$ An award will be reviewable for being contrary to public policy for the purposes of art 34(2)(b)(ii) of sch 1 of the Arbitration Act if "it was so flawed that its enforcement would bring into question the integrity of the Court's processes and powers." 111 It requires that a procedural irregularity likely resulted in a substantial miscarriage of justice, which in turn requires that the complained of finding be central to the reasoning of the award. $^{112}$

63 The scope for review is narrower, then, than that available in respect of appeals on the decisions of State courts where ordinarily the decision of a court of first instance may be appealed. Likewise it is narrower than the review available for the decisions of domestic administrative tribunals. ${ }^{113}$

64 For instance, grounds for review have been confined to exclude the possibility of review of whether there was any evidence to support a factual finding by an arbitrator by the decision of the Court of Appeal in. ${ }^{114}$ Such decisions indicates a broader policy of deference to arbitral tribunals to support the policy of the Arbitration Act 1996, that being the finality of arbitration awards and limited judicial intervention. ${ }^{115}$ As Dobson J observed in Petroleum Mining Co Ltd v Shell (Petroleum Mining) Co, the powers of the court are limited to a: ${ }^{116}$ confined supervisory jurisdiction where the Arbitration Act 1996 ... is premised on the basis that for those who elect by contract to resolve

109 Other countries with similar elaborations are Scotland, Singapore and Australia: Williams and Kawharu, above n 13, at 488.

110 Gary Born International Arbitration: Law and Practice (Kluwer International Law, The Netherlands, 2012) at 401-3. Williams and Kawharu, above $\mathrm{n} 13$, at 762 .

${ }^{111}$ Williams and Kawharu, above n 13, 123.

${ }^{112}$ At 124

${ }^{113}$ See generally Joseph, above n 51, at [22.8.5].

114 Gold and Resource Developments (NZ) Ltd v Doug Hood Ltd [2000] 3 NZLR 318 (CA) at [55].

115 At [55].

116 Todd Petroleum Mining Co Ltd v Shell (Petroleum Mining) Co Ltd HC Wellington CIV-2008-485-2816, 17 July 2009 at [24]. 
their differences by arbitration and where they thereafter do so, then the autonomy of that process is to be respected and there are only narrowly confined circumstances in which the court can intervene.

65 Such limited grounds for review infringe the guarantee under $\mathrm{s}$ 27(2). Perhaps the rationale for confined grounds of review is consistent with the White Paper's conception of the scope of the guarantee, viz. - that it would "permit only the regulation of the right [but] not ... authorise its denial." 117 The right to access review is regulated to deliver the policy end of efficient dispute resolution.

66 The objective of finality of decision-making, a central advantage of international commercial arbitration, ${ }^{118}$ would be compromised by grounds of review exceeding the established parameters of the New York convention. Such is the tension of the BAT: expanding the grounds for review because of potential concerns raised by this paper risks reducing the purported economic benfits of the BAT, because one of the key benefits of arbitration is finality at the expense of review.

\section{Conclusion}

67 I refrain from a s 5 analysis of the justifiability of these limitations. ${ }^{119}$ So far as the BAT might entail prima facie infringement of rights protected by the BORA, such infringements likely amount to a justifiable limitation on the relevant rights. Indeed, it has been argued that the BAT improves the right to access justice by giving parties access to effective justice, rather than limiting that right. ${ }^{120}$ It is arguable that arbitral tribunals meet the natural justice standards required by the BORA. ${ }^{121}$ As regards the right to review of decisions, it has been noted that the White Paper indicated that the right could be regulated. Given awards a reviewable on some grounds, the right can hardly be said to be denied.

\footnotetext{
117 Palmer "A White Paper", above n 89, at [10.175]. The White Paper is at times unclear, however, as to whether descriptions of the intended effect of the guarantee were matters of scope, or of justification. See generally Butler and Butler, above $\mathrm{n} 79$, at ch 6 .

${ }^{118}$ Born, above $\mathrm{n} 110$, at 13 .

${ }^{119}$ See instead Butler and Herbert, above n 6, (forthcoming).

${ }^{120}$ Petra Butler and Herbert, above n 6, (forthcoming).

${ }^{121}$ But see discussion below at [179].
} 
Nonetheless, the BORA is not the full measure of the New Zealand constitution - it focusses on an important, but not comprehensive matter, that being the relationship between the State and the individual. In the following parts, this paper looks to the broader questions of constitutionality: those concerning the effect of the BAT on the relationship between branches of government. The BAT might be a justifiable limitation on individual rights under the BORA, but may nonetheless be an unjustifiable interference with New Zealand's constitutional settlement. These matters are what Joseph describes as questions of "institutional morality ... the moral dimension of public power [which describe] the correct organisation of the State."122

69 For instance, the White Paper suggests that s 27(2) of the BORA "sets out and gives enhanced status to the basic constitutional right to go to court to challenge the legal validity of government actions." ${ }^{123}$ It reflects the importance of the constitutional principle of the rule of law which of course preceded the enactment of the BORA. Similarly, s 27(2) is to serve as a check on privative clauses that purport to restrict judicial review ${ }^{124}$ - an end that preserves the separation of powers. The principles that underlie the relevant BORA provisions are then expressly of a constitutional character. Accordingly, the BORA marks the legislative endorsement of the principles that will be addressed in the next Parts.

\section{$V \quad$ The separation of powers}

The separation of powers, even if not perfectly realised, ${ }^{125}$ is a central constitutional principle of Westminster parliamentary democracies. ${ }^{126}$ The principle requires that the entities exercising legislative, executive and judicial functions should

\footnotetext{
122 Joseph, above $\mathrm{n} 51$, at 2.

${ }^{123}$ Palmer "A White Paper", above n 89, at [10.127].

${ }^{124}$ At [10.127].

${ }^{125}$ The separation can be said to be imperfect because of the degree of fusion of the executive and legislative branches, and the administrative power the executive has in relation to the judiciary.

126 Roger Masterman The Separation of Powers in the Contemporary Constitution: Judicial Competence and Independence in the United Kingdom (Cambridge University Press, Cambridge, 2010) at 227; Ministry of Justice Annual Report 1 July 2010 - 30 June 2011 <www.justice.govt.nz> at 3; Cabinet Office Cabinet Manual 2008 at [4.12].
} 
be independent of one another. The rationale for the division is that power divided is power less dangerous. ${ }^{127}$

71 In constitutions that derive from Westminster, the tripartite separation of powers, first described by Montesquieu in $D e$ l'esprit des loix in 1748, is "an evolved division." 128 As a result, the division is less clear than that in countries with a written constitution that clearly delineates the branches of government. ${ }^{129}$

72 If not written, the lines of separation nonetheless exist. And in any case, even without legal effect, the principle has the normative implication that, having separated the functions of State, they ought remain separate. ${ }^{130}$ Contemporary statements indicate not only that the judiciary is its own branch of government, but that its constitutional role is not a product of actions by the other branches of government: ${ }^{131}$

It is not a creation of Parliament. It is not and cannot be a creature of the executive.

In relation to the judicial function, the separation of powers is given substance in part through the principle of judicial independence. ${ }^{132}$ The constitution guarantees judicial independence and protect the judiciary from legislative or executive usurpation of its powers. ${ }^{133}$ It is questions of that nature that provide the most heat (and the least light) in modern debates about the constitutional status of the judiciary. ${ }^{134}$ But the BAT presents a different concern. Instead of risking the subordination of the judiciary to, say, the executive, the BAT would represent an effort on part of the executive and legislature to bypass the courts, because parties would by

\footnotetext{
127 Geoffrey Palmer "The Legal Framework of the Constitution" in Colin James (ed) Building the Constitution (Institute of Policy Studies, Victoria University of Wellington, Wellington, 2000) 182 at 185.

${ }^{128}$ Priestley, above n 57, at 3.

${ }^{129}$ Consider Article III of the Constitution of the United States of America, which reads: "The judicial power of the United States, shall be vested in one Supreme Court...".

${ }^{130}$ Joseph, above n 51, at 199.

${ }^{131}$ Priestley, above n 57, at 3.

${ }^{132}$ See United Kingdom Select Committee on the Constitution Relations between the executive, the judiciary and Parliament (HL) (2006-07) HL 151 at [27].

${ }^{133}$ Joseph, above n 51, at 199.

${ }^{134}$ See, generally, Priestley, above n 57.
} 
default be subject to the authority of arbitrators and not the State courts.

74 This raises three main concerns. The first is that access to State courts may, as Elias CJ, extra-judicially, suggested, fall into "the basket of fundamental rights"-rights not of a statutory character, but of the common law. ${ }^{135}$

Second, from an instrumental perspective, the policy might weaken the judiciary such that it is less effective at performing other functions which are undoubtedly constitutional in nature. For instance, it is said that "the separation of powers is crucial in guaranteeing the integrity of the courts' performance of [judicial review]". ${ }^{136}$

76 Finally, and the focus of this part, it may not be constitutional to substantially curtail the powers of one of the three necessary branches of government. Just as it would be inappropriate for the courts to usurp the powers of Parliament, it would be inappropriate for the Parliament to remove the powers of the courts. The essential question is this: how far can the legislature go in disestablishing the courts' jurisdiction?

77 This part will deal only with the second of those three arguments. The justification for access to State courts as a constitutional right is made below in Parts VII and VIII. Matters of judicial review and institutional capacity are dealt with in relation to the rule of law, below and Part VI.

\section{A Judicial power under written constitutions}

Before looking to the judicial power under Westminster constitutions, it will be useful to look at conceptions of judicial power in the United States, with particular reference to arbitration, because it brings into sharp relief the notion of a judicial power.

79 Article III of the US Constitution provides that " $t \mathrm{t}]$ he judicial power of the United States, shall be vested in one Supreme

\footnotetext{
${ }^{135}$ Sian Elias "Sovereignty in the 21st Century: Another Spin on the MerryGo-Round" (address to conference on Sovereignty in the 21st Century, Institute for Comparative and International Law, University of Melbourne, March 2003) at 21, citing Anisminic Ltd v Foreign Compensation Commission [1969] 2 AC 147.

${ }^{136}$ Bingham, above $\mathrm{n} 74$, at 78 .
} 
Court...”. In CFTC $v$ Schor ${ }^{137}$ the Supreme Court of the United States identified both a personal right conferred by Art III and a non-waivable component, the latter of which can only be overcome by way of a multi-factor balancing test. ${ }^{138}$ Rutledge is, by contrast, of the view that there is no personal right emerging from Article III; instead it is a matter of conferring the judicial power of the US. ${ }^{139}$ This disagreement over the character of the provision is illustrative of the idea of the court as a constitutional actor with a right to persist, independent of questions of individual rights of access; that is, it is a matter of institutional morality. ${ }^{140}$

80 Enforceability of arbitral awards is the consequence of judicial policy, but also that of the executive and legislature insofar as each have entered into international agreements or legislated to facilitate the enforcement of awards. Rutledge observes that separation of powers principles "generally prohibit the commandeering of another branch of government". ${ }^{141}$ Arbitration then "diminishes the power of the judicial branch ... [by] stripping federal courts of the power to interpret the meaning of federal law and erecting a system by which others - namely arbitrators - can define it." "142 Arbitration has the effect of undermining the power of the judicial branch to varying degrees, depending on the extent to which it is supervised by the judicial branch.

In the same way that administrative tribunals are a common feature in New Zealand, there is "too much precedential water under the bridge" to pursue a literalist attitude to Article III. Congress has not infrequently foreclosed Art III judicial review with administrative agencies and the courts have tolerated its efforts. ${ }^{143}$ Nonetheless, separation of powers issues are more acute in arbitration because the arbitrators are explicitly determining matters of law on a much broader scale than administrative tribunals, which are often confined to particular areas of law and are superintended by the courts.

${ }^{137}$ CFTC v Schor (1986) 478 US 883.

${ }^{138}$ Rutledge, above n 93, at 18.

139 At 19.

${ }^{140}$ See discussion above at [68].

${ }^{141}$ Rutledge, above n 93, at 23.

142 At 22.

143 At 24. 
82 To remedy these separation of powers concerns, Rutledge prefers what he terms a modified form of "appellate review theory", drawing on the work of Richard Fallon. ${ }^{144}$ The constitutionality of non-Article III tribunals can be preserved by adequately searching review of the relevant decision. ${ }^{145}$ Fallon concluded that in respect of matters of constitutional law, it was necessary for courts to have an opportunity for de novo review of arbitral awards for a scheme of arbitration to be constitutional. ${ }^{146}$

83 Relevant to the BAT, he considers that consent is a relevant factor in that it can amount to a waiver of the Article III rights: "when both parties are satisfied that the adjudicatory systems treats them fairly, there is substantial assurance that the agency is not generally behaving arbitrarily or offending separation-ofpowers values." ${ }^{147}$ But, even then, consent does not ameliorate separation-of-powers concerns. ${ }^{148}$ Consent to a system indicates that the parties are not concerned about separation of powers matters, but there may exist nonetheless in terms of constitutional significance insofar as it implicates third party interests, such as in the application of securities law. "In a truly involuntary arbitration, such as the BIT arbitrations", Rutledge argues that "the fairness concerns remain dominant and, thus, so too does the need for Article III review."149

84 Rutledge concludes that, though close, private commercial arbitration is constitutional under the modified appellate review theory. The lack of review of factual errors does not present Article III concerns, as many non-judicial adjudicators are free to determine factual matters without supervision of the courts. ${ }^{150}$ Regarding matters of constitutional law, the scope of review available under the FAA and the NYC is sufficient, ${ }^{151}$ but only so far as the doctrine of manifest disregard survives,

${ }^{144}$ Richard H Fallon "Of Legislative Courts, Administrative Agencies and Article III" (1988) 101 Harv L Rev 915.

${ }^{145}$ Rutledge, above n 93, at 27.

${ }^{146}$ Fallon, above n 144, at 976.

147 At 991-2.

${ }^{148}$ Rutledge, above n 93, at 31 .

${ }^{149}$ At 37.

${ }^{150}$ At 46.

${ }^{151}$ At 46-7. 
which is uncertain following Hall Street Associates. ${ }^{152}$ This is the case due to the voluntariness of arbitration which allows for a reduced role for federal courts. ${ }^{153}$ For instance, he considers a scheme that entirely forecloses review of the decision of an arbitrator's decisions, even in cases of manifest disregard of the law, to be unconstitutional for infringing on the separation of powers. ${ }^{154}$

85 The US commentary indicates that, in a jurisdiction with a clearly demarcated judicial power, there is a feat that arbitration raises constitutional concerns that can only be resolved by sufficient involvement of the courts. But that conclusion survives in part because, unlike under BAT arbitration, the parties have expressly consented to arbitration.

\section{B Judicial power in Westminster constitutions}

86 The High Court exercises powers emergent from the common law and equity, and has inherent jurisdiction. ${ }^{155}$ The inherent jurisdiction it exercises is that developed by the Royal Courts of justice "from medieval times, which included the jurisdiction to superintend inferior courts and tribunals." 156

87 Section 16 of the Judicature Act 1908, a part of New Zealand's constitution, ${ }^{157}$ reads:

The court shall continue to have all the jurisdiction which it had on the coming into operation of this Act and all judicial jurisdiction which may be necessary to administer the laws of New Zealand.

88 In this Part reference will therefore be made to the constitutional status of the courts of the United Kingdom,

${ }^{152}$ Hall Street Associates LLC v Mattel Inc (2008) 552 US 576. Rutledge, above $n$ 93, at 48-9.

${ }^{153}$ At 47.

154 At 48 .

155 Joseph, above n 51, at [21.5.3]; Anthony H Angelo Constitutional Law in New Zealand (Kluwer Law International, The Netherlands, 2011) at [226].

${ }^{156}$ Joseph, above n 51, at [22.3.6].

${ }^{157}$ Law Commission Review of the Judicature Act: Towards a Consolidated

Courts Act (NZLC IP29, 2012) at [1.1]. 
because the New Zealand courts stem from the same sovereign authority - their jurisdiction has been continued. ${ }^{158}$

89 The preservation of the role of the courts, and their inherent jurisdiction is a complicated matter. The Law Commission, in its recent review of the Judicature Act 1908 suggested a unitary courts act that would organise the judiciary in one statute. Notwithstanding the Commission's proposal of using the language of 'continuation' in statutory reference to the jurisdiction of the High Court, the judges were concerned about the possibility of the constitutional status of the judiciary being diminished. ${ }^{159}$

90 The submission of the Law Society captures the perspective well. It argued that reforms ought to: ${ }^{160}$

preserve fundamental features of our constitution. ... One such feature is that Superior Court judges - that is, Her Majesty's judges signified by the Judicature Act hold a constitutional office. Together, such judges constitute the judicial branch of government. The organisation of the Superior Courts appellate structures has, of course, been accomplished by legislation, but the foundation from which all proceeds is the inherent jurisdiction of a judge to deal with all justiciable issues. This is the basis of judicial review, for example. Judicial powers can, of course, be augmented and regulated in various ways, and in particular contexts, by Parliamentary enactments. But the origin of those powers lies with the judicial power of the Sovereign, recognised since the early $17^{\text {th }}$ century to be exercisable only through the Sovereigns judges. ... [It is therefore] important that the detail of any reforming legislation be carefully considered so that it preserves the continuity of these constitutional arrangements - just as the Constitution Act itself did for the law making powers of Parliament.

91 The High Court then undoubtedly occupies a unique constitutional position. ${ }^{161}$ It has been described as bearing

158 The Judicature Act 1908 uses the language of continuation. The legislation prior to that Act vested the New Zealand courts with the jurisdiction of the courts in England: Joseph, above n 51, at 846.

${ }^{159}$ Law Commission Review of the Judicature Act 1908: Towards a New Courts Act (NZLC R126, 2012) at [1.13].

160 At [1.14].

161 At v. 
sovereign power. It exercises sovereign authority in concert with Parliament. So Sedley writes that: ${ }^{162}$

It is in Parliament and the courts, each exercising a discrete though interdependent function of the State, the legislative and the judicial, that the sovereignties of the State reside.

92 The rule of law, said Lord Bridge in $X \mathrm{Ltd}$, "rests upon twin foundations: the sovereignty of the Queen in Parliament in making law and the sovereignty of the Queen's courts in interpreting and applying the law." 163 In Tangiora $v$ Wellington District Legal Services Committee, the Privy Council used similar language of sovereignty. Referring to the bodies listed as judical authority in the Legal Services Act 1991 the Committee said: ${ }^{164}$

Every such body forms part of the legal system of New Zealand in that it exercises the adjudicative functions of New Zealand. The jurisdiction of such a body is coercive, not consensual. It exercises in the name of the State the sovereign adjudicative power of the State.

93 And in Arbitrators Institute of New Zealand Inc $v$ Legal Services Board Heron J described judicial power as: ${ }^{165}$

the power which a sovereign authority necessarily has to determine disputes between its subjects, or between itself and its subjects.

94 Sovereign authority is of the common law. The modern common law, suggested Lord Cooke, contains two unalterable principles: "the operation of a democratic legislature and the operation of independent courts."166

While not so clearly established as that in the United States, it appears then that under the New Zealand constitution sovereign authority is exercised by the courts and the Parliament in

${ }^{162}$ Stephen Sedley The Common Law and the Constitution" in Lord Nolan of Brasted and Stephen Sedley The Making and Remaking of the British Constitution (Blackstone Press, London, 1997) at 26-27, cited in Joseph, above $\mathrm{n} 51$, at 574.

${ }^{163}$ X Ltd v Morgan-Gampian Ltd [1991] 1 AC 1 at 48.

${ }^{164}$ Tangiora $v$ Wellington District Legal Service Committee [2000] 1 NZLR

17 (PC) at 22 (emphasis added).

${ }^{165}$ Arbitrators Institute of New Zealand Inc v Legal Services Board [1995] 2 NZLR 202 (HC).

${ }^{166}$ Robin Cooke "Fundamentals" (1988) NZLJ 158 at 165. See also Law Commission, above n 157, at [4.9]. 
concert, albeit the respective judicial and legislative functions. In the author's view, this reflects the settled "institutional morality" of the New Zealand constitution - it is a matter of the correct allocation of State authority. The State must see that it provides a venue for the exercise of that power. Accordingly, Lord Diplock described access to the courts as a constitutional principle: ${ }^{167} \mathrm{a}$

Every civilised system of government requires that the State should make available to all its citizens a means for the just and peaceful settlement of disputes between them as to their respective legal rights. The means provided are courts of justice to which every citizen has a constitutional right of access in the role of plaintiff to obtain the remedy to which he claims to be entitled in consequence of an alleged breach of his legal or equitable rights by some other citizen, the defendant.

96 The foregoing gave a general overview of some conceptions of the role of the courts in the New Zealand constitution, and underscored the importance of the separation of powers as a matter of institutional morality. To alter the jurisdiction of the courts is to alter the authority of one part of the sovereign.

97 An examination of the jurisprudence and commentary concerning ouster (or "privative") clauses will be useful for an assessment of the separation of powers implications of the BAT. Ouster clauses are legislative provisions that purport to exclude the jurisdiction of a court to deal with a matter that would otherwise be within its jurisdiction. ${ }^{168}$

98 The effect of the ouster clause is generally to attempt to vest conclusive jurisdiction over a dispute in a non-judicial body, often an executive administrative agency, or a tribunal of sorts that sits outside the ordinary judicial hierarchy. By way of analogy, the effect of the BAT would be to vest adjudicative power, subject to very minimal supervision by the courts, in what might otherwise fairly be described as a private tribunal.

99 We have already seen, in relation to the US Constitution, the clear articulation of a judicial power. Westminster constitutions

${ }^{167}$ Bremer Vulkan Schiffbau Und Maschinenfabrik v South India Shipping Corporation Ltd [1981] AC 909 (HL) at 977.

${ }^{168}$ Edlin, above n 49, at 70. 
have no written component that so expressly establishes or demarcates judicial power. The controversy over ouster clauses is, in the author's view, provides the most vivid expression of the judicial power as being beyond the reach of the other organs of State. The constitutional propriety of ouster clauses can, then, be used a yardstick for the similar assessments as regards the BAT.

100 Privative clauses are a challenge to judicial autonomy, ${ }^{169}$ and to the separation of powers. Accordingly, attempts by the legislature to confine the jurisdiction of the courts to review State action is a threat to the "institutional position and constitutional obligation" of the courts. ${ }^{170}$ The right of access to the courts need not be considered, as it may traditionally be approached, ${ }^{171}$ as a matter of an individual right, but rather as an issue of the relationship between courts and the other branches of government as institutions; the relationship between the constituent organs of State: ${ }^{172}$

Rather than conceive of the right of access to the courts in terms of what is logistically necessary for purposes of litigation (from the litigant's perspective), [the analysis can be reconfigured] in terms of what is constitutionally necessary for purposes of adjudication (from the common law's perspective).

101 The Court of Appeal in NZ Drivers' Association stated that there is a "traditional reluctance, based on fundamental constitutional principles, to allow the jurisdiction of the ordinary Courts to be taken away". ${ }^{173}$ And it boldly went further to say: ${ }^{174}$

we have reservations as to the extent to which in New Zealand even an Act of Parliament can take away the rights of citizens to resort to the

\footnotetext{
${ }^{169}$ Edlin, above n 49, at 70.

170 At 101; Lord Woolf "The Rule of Law and a Change in the Constitution" (2004) 63 CLJ 317 at 328.

${ }^{171}$ The issue is often, though not unreasonably, framed as being: "how is the poor man or woman to be enabled to assert his or her rights at law?" Bingham, above n 74, at 77 .

172 Edlin, above n 49, at 72.

${ }^{173}$ New Zealand Drivers' Association v New Zealand Road Carriers [1982] 1 NZLR 374 (CA) at 390, per Cooke, McMullin and Ongley JJ.

${ }^{174}$ New Zealand Drivers' Association v New Zealand Road Carriers [1982] 1 NZLR 374 (CA) at 390, per Cooke, McMullin and Ongley JJ.
} 
ordinary Courts of law for the determination of their rights.

102 Discussing the principles underlying that decision, Lord Cooke observed: ${ }^{175}$

the existence and functioning of independent Courts [is a fundamental premise].... If an Act were to provide that the superior and other Courts should cease to hear cases ... and thereafter all indictments, informations, suits, actions or other justiciable proceedings or issues whatsoever should be determined within a hierarchy of administrative tribunals, with members holding office at the Pleasure of a Minister, it could hardly stand... The Courts have a constitutional role and it is their duty to fulfil it. ... Of course that does not prevent restructuring of the Court system. For instance, In New Zealand by an Act of 1987 a Labour Court has been created... It has taken over, to the exclusion of the High Court but subject to rights of appeal to the Court of Appeal, jurisdiction over (inter alia) tort and inducement of breach of contract actions connected with strikes or lockouts, including the power to grant injunctions. Its Judges hold office during the traditional "good behaviour", subject to removal by Her Majesty upon address of the House of Representatives. There appears to be nothing constitutionally objectionable in these provisions. What would be constitutionally objectionable, I suggest, would be to try to transfer the essentially judicial part of the work to a body that is not a Court in the same sense.

103 The approach of both United States and English courts to ouster clauses reveals important features, suggests Edlin, of the: ${ }^{176}$

subtle underlying dynamics of institutional relationship and to examine shared commitments to judicial independence and to a correlative right to seek review of governmental action in and through the judiciary. Reading these cases together, I argue that this right should be conceived in the United States as it is articulated in England: a fundamental right of access to the courts.

104 The importance of review has led to a the courts resisting privative clauses. It is insufficient that the provision indicate

175 Cooke, above n 166, at 164.

${ }^{176}$ Edlin, above n 49, at 71. 
that the decision of the tribunal is to be "final". ${ }^{177}$ Parliament must expressly legislate to the effect that it intends to deprive citizens of access to the courts. ${ }^{178}$ The courts will take a restrictive approach, requiring "clear statutory wording" to oust the High Court's jurisdiction. ${ }^{179}$ Nonetheless, Tipping J observed in O'Regan that it was "perfectly possible" for Parliament to render the determinations of a decision-maker absolutely conclusive. ${ }^{180}$

105 The general refusal to abide ouster clauses suggests, however, a stronger principle at play. ${ }^{181}$ This attitude has a substantial vintage. ${ }^{182}$ In Young $v$ Police, Randerson $\mathrm{J}$ suggested that, while Parliament may regulate review by way of statute so far as is consistent with the BORA, there may be limits to its powers in this respect that emerge from the constitution. Thus: ${ }^{183}$

The Judges of the High Court retain the inherent jurisdiction to modify the grounds of judicial review at common law as they have done traditionally for many years. Parliament may also modify the statutes conferring powers of judicial review, but only within the constitutional constraints of s 27(2) and s 5 of the Bill of Rights Act, as well as constitutional law generally.

106 The conclusion to be drawn from the foregoing material is that there is a strong constitutional principle that tells against diminishing the jurisdiction, and with it the power, of the courts.

\section{$C$ Effect of BAT on judicial power}

107 This section examines the effect of the BAT on the judicial power and concludes that it would grant sovereign authority to arbitral tribunals to the exclusion of the courts from their

${ }^{177} R$ v Medical Appeal Tribunal, Ex parte Gilmore [1957] 1 QB 574 per Romer LJ.

178 Whitlam, $R$ (on the application of) v Lord Chancellor [1997] EWHC Admin 237 at [27], per Laws J.

${ }^{179}$ Zhaoui v Attorney-General [2005] 1 NZLR 577 (SC) at [44].

${ }^{180}$ O'Regan v Lousich [1995] 2 NZLR 620 at 626-627, per Tipping J.

${ }^{181}$ See generally Joseph, above n 51, at [22.9.3].

182 See generally S A de Smith "Statutory Restriction of Judicial Review" (1955) 18 MLR 575 where the control of administrative action is traced to the practice of the Court of King's Bench in the late $17^{\text {th }}$ century.

${ }^{183}$ Young v Police [2007] 2 NZLR 382 at [37] (emphasis added). 
traditional domain. Ordinarily, the power of the arbitrator to decide the dispute was understood to arise from the private, consensual, agreement between the parties. ${ }^{184}$ Though there is statutory control of arbitration, it remains essentially contractual. ${ }^{185}$ If, even then, the arbitrator is "quasi-judicial" in nature, ${ }^{186}$ under the BAT arbitration, the arbitrator will be much closer to exercising actual judicial function. In Tangiora $v$ Wellington District Legal Service Committee, ${ }^{187}$ the Privy Council observed that a:

... private arbitrator, whose authority derived from the consent of the parties and not from the State, was not a "judicial authority"...

108 But in Arbitrators' Institute of New Zealand Inc $v$ Legal Services Board Heron J expressed the view that: ${ }^{188}$

There may be ... situations where an arbitrator is acting on authority of the Court or the State and may, depending on the circumstances, be an "administrative tribunal or judicial authority".

109 It is the view of the author, then, that the BAT tribunals would be in effect exercising the sovereign authority of the New Zealand courts while being outside of that system. Their judicial authority would flow, though, not from the continuing jurisdiction of the courts based on their position as a constitutional actor, but because the purported power was granted to them by the legislative and executive branches.

110 While it is perfectly constitutional to permit private parties to establish by consent the jurisdiction of the arbitrator and accordingly proscribe in various ways the authority of the courts to supervise the arbitral proceedings, where the jurisdiction flows from an exercise of State power, the courts'

\footnotetext{
${ }^{184}$ Emmanuel Gaillard and John Savage (eds) Fouchard, Gaillard, Goldman on International Commercial Arbitration (Kluwer International Law, The Hague, 1999) at [7].

185 Bremer Vulkan Schiffbau Und Maschinenfabrik v South India Shipping Corporation Ltd [1981] AC 909 (HL) at 977 at 999, per Lord Scarman.

${ }^{186}$ Jivraj v Hashwani [2011] UKSC 40, [2011] WLR 1872 at [41].

187 Tangiora $v$ Wellington District Legal Service Committee [2000] 1 NZLR 17 (PC) at 20.

188 Arbitrators' Institute of New Zealand Inc v Legal Services Board [1995]

2 NZLR 202 (HC) at 207. This view was endorsed by the Judicial Committee in Tangiora $v$ Wellington District Legal Service Committee [2000] 1 NZLR 17 (PC) at 20.
} 
jurisdiction may not be so confined without injury to the constitution. As Lord Diplock observed: ${ }^{189}$

it was held by the Divisional Court that the general supervisory jurisdiction of the High Court over the proceedings of inferior courts and tribunals extended only to "bodies on whom Parliament has conferred statutory powers and duties which, when exercised, may lead to the detriment of subjects who may have to submit to their jurisdiction." These bodies would include arbitrators appointed to conduct a statutory arbitration to whose jurisdiction parties to a particular kind of dispute are compelled to refer it for determination, but they do not include arbitrators appointed pursuant to private arbitration agreement. In relation to private arbitrations the jurisdiction of the High Court to supervise the conduct of the arbitration is confined to exercising the powers conferred upon it by the Arbitration Acts 1950 and 1979 (though the latter Act does not apply to the arbitration in the instant case). The reason for this distinction is that the jurisdiction of an inferior court or statutory tribunal or arbitrator over the person who wishes to resist the claim is compulsory whereas the jurisdiction of an arbitrator over both parties to a private arbitration agreement is consensual only.

111 Accordingly, there is a distinction between arbitral tribunals (based on consent) and inferior courts generally. In the context of consensual arbitration, the approach of most jurisdictions, including New Zealand, is to take a restrictive approach to the grounds available for the setting aside of an award or the refusal of its enforcement. This is a sensible approachconsent is a sound proxy for fairness as assessed by the parties. ${ }^{190}$

112 In absence of that fundamental marker of consent, the process is no longer arbitration and one of the core rationales for judicial restraint is absent. The tribunal is exercising authority conferred on it by Parliament, and not by the parties themselves.

\footnotetext{
189 Bremer Vulkan Schiffbau Und Maschinenfabrik v South India Shipping Corporation Ltd [1981] AC 909 (HL) at 977 at 978.

${ }^{190}$ Rutledge, above n 93, at 37.
} 
113 The courts, faced with awards made under BAT arbitration, might be more willing to make interventions for several reasons. First, rather than jurisdiction by contract, the BAT tribunal derives its authority from the State. It is a fundamental function of the courts of justice to supervise the exercise of power by other branches of government. Indeed, the Law Commission in its report on arbitration recognised that, generally, "the State should ... impose on parties to disputes arising under statutes, as the means of resolving those disputes, only official bodies such as courts and statutory tribunals." 191

114 Many non-judicial bodies exercise adjudicative functions in New Zealand, such as the Tenancy Tribunal, the Social Security Commission, and the Taxation Review Authority. ${ }^{192}$ The divide between courts of judicature and administrative tribunals is, however, not very clear. ${ }^{193}$ The labelling of a body as a court or a tribunal is not conclusive. ${ }^{194}$ The courts will without express permission exercise the inherent jurisdiction to supervise inferior tribunals. In Attorney-General v Reid the Full Court of the High Court held that: ${ }^{195}$
normally when an inferior Court exceeds jurisdiction the issue will be brought before this Court by way of review or by way of extraordinary remedy and that this Court exercises its general supervisory jurisdiction even if there is no right of appeal in respect of the inferior Court.

115 Perhaps, then, a more intense species of review would be used in relation to BAT awards than is used in respect of arbitration awards generally. The language of the Arbitration Act 1996 does not conclusively define "public policy", leaving scope for greater judicial intervention. This would be redolent of Rutledge's approach — the "modified appellate review theory". ${ }^{196}$ This would sit well with the conclusion that Parliament has authority to divest the courts of jurisdiction, ${ }^{197}$

\footnotetext{
${ }^{191}$ Law Commission, above n 40, at 97.

${ }^{192}$ See Joseph, above n 51, at 213.

193 At [21.5.1]; K J Scott The New Zealand Constitution (Oxford University Press, London, 1962) at 156.

${ }^{194}$ Attorney-General v O’Neill [2008] NZAR 93 (HC)

195 Attorney-General v Reid [2000] 2 NZLR 377 (HC) at [29].

196 See above at [82]-[84].

${ }^{197}$ O'Regan v Lousich [1995] 2 NZLR 620 at 626-627, per Tipping J.
} 
while guarding against the risks of the BAT that raise constitution questions in the first place.

116 Or in the alternative, the courts might react more strongly. Lord Steyn suggested that there might exist "exceptional circumstances involving an attempt to abolish judicial review or the ordinary role of the courts [where a court] may have to consider whether this is a constitutional fundamental which even a sovereign Parliament acting at the behest of a complaisant House of Commons cannot abolish."198

117 That would be, according to Edlin, loyalty to the constitution: ${ }^{199}$

The recognition and enforcement of [the right to judicial review] by English and United States courts, even against legislative attempts to preclude their jurisdiction, represents the preservation of the judiciary's traditional role and responsibility rather than defiance toward the legislature.

118 In any case, the strength of the presumption against ouster clauses - the requirement of clear language, and the reticence of the courts to acquiesce even in the face of such languagesuggests that what is at stake is a constitutional principle. Whatever the courts' response to the BAT might be, the 'ought' of the constitution might demand that we think carefully before pursuing such a policy.

\section{Summary}

119 Separation of powers arguments have little force in relation to delegating adjudicative functions to administrative tribunals provided that they act in accordance with principles of natural justice and are amenable to supervision by the courts. ${ }^{200}$ The BAT tribunals would operate according to the principles of natural justice, ${ }^{201}$ but are only subject to review on exceptionally narrow grounds.

${ }^{198} R$ (Jackson) v Attorney General [2005] UKHL 56, [2006] 1 AC 262 at [102], per Lord Steyn (emphasis added).

${ }^{199}$ Edlin, above $\mathrm{n} 49$, at 99.

200 Joseph, above n 51, at 213.

${ }^{201}$ See discussion above at [54]-[55]. 
120 Even those that argue from the ideal of the separation of powers often return to an instrumentalist justification: whether the presence of the courts promotes the accountability of the other branches of government. Accordingly, if orthodox arguments from the separation of powers are unpersuasive, the same concerns can be rephrased in a more instrumentalist manner as rule of law concerns. The separation is a key constitutional principle as it is "a necessary condition of the rule of law and limited government." ${ }^{202}$ It is closely related with the maintenance of the rule of law, the implications of which are addressed in the next Part.

\section{The rule of law}

121 Arguments from the rule of law are challenging. The meaning of the term is amorphous, and there are many competing definitions. Palmer opines that a definition that "has broad enough support and agreement that we can use it effectively in law" is difficult to pin down. ${ }^{203}$

122 It is though, a central principle of Westminster constitutions. In $R v$ Jackson the House of Lords described it as the ultimate controlling factor on which our constitution is based."204 Despite its vagueness, there is statutory recognition of the rule of law in New Zealand in the form of s 2 of the Supreme Court Act 2003, which reads:

Nothing in this Act affects New Zealand's continuing commitment to the rule of law and the sovereignty of Parliament.

123 This section will draw out several articulations of the rule of law that are relevant to the operation of the BAT.

124 Tamanaha famously identified three clusters of concepts recurrent in various expositions of the rule of law: (i) government limited by law, (ii) formal legality, and (iii) rule of

\footnotetext{
202 Joseph, above $\mathrm{n} 51$, at 226.

${ }^{203}$ Matthew Palmer "Assessing the Strength of the Rule of Law in New Zealand" (paper presented to the New Zealand Centre for Public Law Conference on "Unearthing New Zealand's Constitutional Traditions", August 2013) at 2.

${ }^{204} R$ (Jackson) v Attorney General [2005] UKHL 56, [2006] 1 AC 262 at [107], per Lord Hope.
} 
law not man. ${ }^{205}$ Waldron describes the central plank as the principle that: ${ }^{206}$

people in positions of authority should exercise their power within a constraining framework of public norms rather than on the basis of their own preferences, their own ideology, or their own individual sense of right and wrong.

125 From these conceptions I suggest the principles relevant to assessing the BAT are, first, that government limited by law requires that exercise of State authority be subject to control by another, independent, State authority, such as courts. Second, for there to be rule of law, that is publically promulgated norms of general application, it is necessary that the role of interpreting the law be reserved to a State authority other than that which produces the law. That latter role should be performed in a public manner by one organ of State. So far as it is tolerable to devolve interpretation, as in, say, the case of administrative tribunals, it is necessary that the ordinary interpretative authority - that is, the courts - be able to correct and control the actions of devolved interpreters.

126 Such is necessary for the fulfilment of Dicey's proviso that government action be subject to the general law. ${ }^{207}$ And so Bingham observed of the mother Westminster constitution that the rule of law requires that: ${ }^{208}$

all persons and authorities within the State, whether public or private, should be bound by and entitled to the benefit of laws publicly and prospectively promulgated and publicly administered in the courts.

127 The essential argument of this Part is that the jurisdiction of State courts to superintend the conduct of public bodies and inferior tribunals (including BAT tribunals) is essential to maintaining the constitutional principle that such entities must act in accordance with the law; or, in other words, that the rule of law is to be maintained. ${ }^{209}$

\footnotetext{
205 See generally Brian Z Tamanaha On the Rule of Law: History, Politics, Theory (Cambridge University Press, Cambridge, 2004).

${ }^{206}$ Waldron "The Concept and the Rule of Law", above n 61, at 5.

207 Tamanaha, above n 205, at 117.

208 Bingham, above n 74, at 69.

${ }^{209}$ Joseph, above n 51, at 847 .
} 
128 So far as the BAT places the sovereign power to use coercive State force, and the power to interpret the law, in an arbitral tribunal it undermines the rule of law, unless it allows for the interpretative authority of the State to supervise the exercise of those powers. Because the BAT provides for only exceptionally limited grounds of review, this paper concludes that it is not consistent with the rule of law.

129 The subsequent sections examine the rule of law in terms of two fundamental threads: (A) the interpretative role of the courts, (B) the review role of the courts. Thereafter will be an assessment of the role of (C) voluntariness in justifying departures from the rule of law, and (D) an exploration of some possible constitutional limitations on attempts to subvert the rule of law.

\section{A Preserving the interpretative role}

130 The court, being the primary law-applying institution in the New Zealand legal system, has reserved to it the power to identify what the law is. ${ }^{210}$ In relation to the determinations of administrative agencies, upholding the rule of law requires that the meaning of a statute is "always a question of law for the courts." 211 The courts have a constitutional obligation to rule on questions of law, though that role may be constrained by statute. $^{212}$ Removing that function to BAT tribunals without significant oversight from the courts is an infringement of that principle.

131 In a way, this argument is a restatement of the principle of the separation of powers, or at least a justification of the separation of powers on the grounds of the rule of law. Indeed, it is said that the rule of law "entails a separation of powers; the independence of the judiciary from the executive and

\footnotetext{
${ }^{210}$ Joseph Raz The Authority of Law: Essays on Law and Morality (Oxford University Press, Oxford, 1979) at 88.

${ }^{211}$ Wool Board Disestablishment Co Ltd v Saxmere Co Ltd [2010] NZCA 513, [2011] 2 NZLR 442 at [116]. See similarly, but in relation to the legislature, $R$ (Jackson) v Attorney General [2005] UKHL 56, [2006] 1 AC 262 at [51].

${ }^{212}$ Peters v Davison [1999] 2 NZLR 164 (CA) at 188.
} 
legislature." 213 It would be contrary to the rule of law, then, for the executive and legislative branches to establish an essentially compulsory jurisdiction alternative to that of the courts, as it usurps the courts' interpretative role.

132 Dworkin argues that the rule of law: ${ }^{214}$

insists that force not be used or withheld, no matter how useful that would be to ends in view, nor matter how beneficial or noble these ends, except as licences or required by individual rights and responsibilities flowing from past political decisions about when collective force is justified.

133 A part of that political decision-making process is the interpretative role of the courts. It is the place of the courts to "make authoritative declarations of what the law is, which obligations must be performed and which responsibilities must be discharged." 215 That requires, the author suggests, a singular judiciary, rather than multiple jurisdictions.

134 Encouraging otherwise similar dispute to be heard in different tribunals subverts the rule of law by undermining the unified application of the substantive law. Speaking of administrative tribunals generally, or "specialist courts", Heydon criticises modern neglect of Dicey's concern that law be applied by unitary rules in general courts. Heydon's general complaint is that the isolation from the general body of law results in departures from the "general standards of the ordinary courts". ${ }^{216}$ But there are also concerns about the way that arbitral tribunals may apply substantive law in a manner different to that of State courts, and/or differently to other arbitral tribunals.

135 Varying application of substantive law is contrary to the rule of law, as in effect, those wielding authority are not acting according to the norms that were available to the public prior to the decision being made. ${ }^{217}$ Publically promulgated rules are

\footnotetext{
213 J D Heydon "What Do We Mean By the Rule of Law?" in Richard Ekins (ed) Modern Challenges to the Rule of Law (LexisNexis, Wellington, 2011) 15 at 20

${ }^{214}$ Ronald Dworkin Law's Empire (Fontana Press, London, 1986) at 93.

${ }^{215}$ Genn, above n 9, at 18 .

${ }^{216}$ Heydon, above n 213, at 29.

${ }^{217}$ Waldron "The Concept and the Rule of Law", above n 61, at 6.
} 
necessary for the rule of law, as without them individuals would not be able to determine what behaviour is lawful. ${ }^{218}$

136 Regardless of judgments as to the ability of arbitrators, the differing institutional structures of arbitral tribunals and State courts by itself encourages divergent application of substantive law. BAT tribunals, not subject to review on matters of law and generally more limited in their access to precedent for want of public decisions, are more likely to depart from uniform application of the law. ${ }^{219}$ Consistent application of substantive law is both essential to the rule of law as a matter of principle, but also necessary for creating the conditions in which the rule of law flourishes - a context where there is public trust in the system of adjudication. Fairness and consistency increase "public trust in the system of justice will be enhanced, thereby serving [the] public good."220

137 Admittedly, arbitrators may have the advantage of subjectmatter expertise in relation to international commercial disputes. ${ }^{221}$ That might improve consistencey, and promote the rule of law. But, because the BAT process is private and confidential, it will be difficult to validate those claims.

138 Moreover, as Rutledge observes, "arbitrators can be arbitrary", in that they have a financial incentive to adopt expansive jurisdiction, may be captured by powerful entities insofar as they desire further business from a party that is more likely to seek arbitration services in the future. ${ }^{222}$ That effect is not necessarily confined to voluntary arbitrations-simply because a party is subject to BAT arbitration does not mean that in other disputes they may be a potential future customer for an arbitrator's services.

139 The argument above is that creating a jurisdiction alternative to that of the State courts is contrary to the rule of law because it usurps the courts' constitutional role as interpreters of the law. But in New Zealand there are many administrative tribunals

\footnotetext{
${ }^{218}$ Raz, above n 210, at 214.

219 See generally Kenneth S Abraham and J W Montgomery "The Lawlessness of Arbitration" (2002) 9 Conn Ins LJ 355.

${ }^{220}$ Jean R Sternlight “Mandatory Arbitration: Is It Just?" (2004) 57 Stanford

L Rev 1631 at 1662.

${ }^{221}$ Butler and Herbert, above n 6, (forthcoming).

${ }^{222}$ Rutledge, above n 93, at 40-1.
} 
that undertake interpretative functions. Certainly efficiency requires placing these functions in bodies other than the courts on occasion. In the next section, this paper addresses the role of review in remedying rule of law concerns arising from the exercise of these powers by non-judicial bodies.

\section{$B$ Review of government action}

140 The BAT substantially confines the review of decisions made by tribunals constituted under it. It is this feature that gives rise to many of the rule of law concerns. Tamanaha suggests that the formal legality element of the rule of law entails "a rulebound order established and maintained by government."223 This requires that the exercise of government authority by one branch is subject to review and control for rule of law compliance by another branch of government - the courts. ${ }^{24}$ Part of a rule-bound order is ensuring that the rules are actually rules-i.e. that they are of general application, applied similarly to similar situations. ${ }^{225}$

141 In the current constitutional order, the rule of law is maintained by the general availability of review. Most exercise of government authority is reviewable-over time the bounds of justiciability have expanded as commitment to rule of law has strengthened. ${ }^{226}$ This principle finds formal expression in s 27 of the BORA. ${ }^{227}$ Indeed, that provision necessarily includes the exercise of authority by the courts. The fact that review of decisions of the Courts are not themselves subject to review is a prima facie infringement of that right, and permissible for the reason that it is a justifiable limitation on the right. ${ }^{228}$

142 One reason that such is justifiable is that there is a formal structure of appeal that generally allows a party two or more appeals after an initial determination. ${ }^{229}$ The suggestion that the

\footnotetext{
223 Tamanaha, above n 205, at 119.

${ }^{224}$ Raz, above n 210, at 217.

225 At 214.

${ }^{226}$ Joseph, above n 51, at [22.5.1].

227 Section 27(2) reads: "Every person whose rights, obligations, or interests protected or recognised by law have been affected by a determination of any tribunal or other public authority has the right to apply, in accordance with law, for judicial review of that determination."

${ }^{228}$ Butler and Butler, above n 79, at [25.3.9].

${ }^{229}$ At [25.3.9].
} 
lack of review is nonetheless an infringement of s 27 of the BORA speaks to the strength of the principle. Applying the same standard, BAT tribunals ought to be subject to an intensity of review concomitant to the power they would exercise. But they would not be.

143 An example of prior legislative interference with the jurisdiction of the courts will be useful for understanding the importance of review. In 1972 New Zealand largely abolished recourse to civil law for personal injury, in a policy decision that confined the jurisdiction of the courts, but also demonstrated a willingness to substitute administrative processes for judicial processes. $^{230}$ The subsequent establishment of various "a-legal" administrative processes that assume roles that perhaps would otherwise be filled by the courts indicates, Palmer suggests, a limited degree of respect for the courts on part of law-reformers. ${ }^{231}$ If, as this paper argues, the BAT is a threat to the separation of powers and the rule of law, was not also the establishment of the accident compensation scheme? Certainly, the effect was to strip the courts of a large part of their civil jurisdiction, much as the BAT would do.

144 The first distinction is that the authority for determining matters that were the province of the courts is a domestic, State authority. It is, accordingly, much closer to the levers of democratic accountability than an off-shore, private institution that operates under conditions of privacy and confidentiality. So far as the separation of powers concerns tend to blend with rule of law issues, the public nature of the authority might limit the risks of judicial function being assumed by a creation of the executive.

145 The second distinction is that, unlike other bodies that have judicial functions by dint of legislative or executive action, the BAT tribunals would not be subject to review in the same manner. New Zealand administrative law demands public authorities confine themselves to their jurisdiction, ${ }^{232}$ for the

\footnotetext{
${ }^{230}$ Palmer, above n 61, at 11.

231 At 11.

232 Though the concept has been somewhat subsumed to the broader descriptor of error of law: Joseph, above n 51, at [23.4].
} 
reason that, were an authority free to exceed its granted jurisdiction "without any check by the Courts, the rule of law would be at an end."233

146 The doctrine of competence-competence permits the arbitrator to determine their own jurisdiction. ${ }^{234}$ This policy finds expression in the subsequent application of a presumption that arbitrators are within jurisdiction for the purposes of enforcement of awards. ${ }^{235}$ Courts have been restrained rather than proactive in refusing to enforce awards on grounds of excess of jurisdiction. ${ }^{236}$ The end result is that BAT tribunals could exceed jurisdiction in a way that would be considered a violation of the rule of law if it were to be done by an administrative tribunal.

147 If the present approach of respecting jurisdictional determinations of arbitrators were to be carried over writ large into the implementation of the BAT, the rule of law would be at risk. A non-State institution would be exercising powers of coercion and interpretation of the law that are properly reserved to the judiciary. That is permissible so far as the judiciary may superintend the exercise of those powers. The confined review jurisdiction is inconsistent with that end, and is accordingly contrary to the rule of law.

\section{Voluntariness and the rule of law}

148 Some of these rule of law concerns exist also in voluntary arbitration. This section argues that, while it is tolerable to suffer departures from the rule of law where one consents to the same, it is unacceptable in the case of the compulsory jurisdiction established by the BAT. It should be kept in mind that "the law of arbitration is written on the basis that the parties have consented to that method of decision-making."237 If the rule of law concerns this paper raises can be dismissed in relation to voluntary arbitration, they cannot in circumstances where the jurisdiction is compulsory.

\footnotetext{
${ }^{233} R v$ Medical Appeal Tribunal, Ex parte Gilmore [1957] 1 QB 574 at 586, per Lord Denning MR.

${ }^{234}$ Born, above $n$ 110, at [4.03].

${ }^{235}$ Born International Commercial Arbitration, above n 32, at 2800.

236 At 2801.

${ }^{237}$ Law Commission, above n 40, at 100.
} 
149 One of the significant benefits of the rule of law is the growth of commerce, and the subsequent improvements to human welfare. In this vein, Rivkin argued that by holding commercial parties to their agreements, arbitrators have created "creating predictability and certainty, [and] they have enabled international commerce." 238 Arbitration in general could be said to improved adherence to the rule of law. Rivkin's conception of the rule of law tolerates a departure from the above descriptions of the rule of law which require the government action to be subject to checks and balances. Those elements of the rule of law are less important where the arbitration is voluntary, because voluntariness is, generally, "a proxy for fairness". ${ }^{239}$ We would not expect parties to opt in to a process that was unfair. But they might opt into a process that was contrary to the rule of law in a global sense, provided that in the local sense - in the world of their dispute-it was suitably efficient or otherwise desirable.

150 We tolerate the divergences from the rule of law in consensual arbitration because inter alia the power exercised by the arbitrator arises from the consent of the parties, and the acquiescence of the State to that preference. ${ }^{240}$ Tamanaha indeed suggests that arbitration generally is a departure from formal legality conceptions of the rule of law Uniform application of a set of rules have an "all-or-nothing consequence, resulting in winners and losers", whereas some relationships, such as commercial ones, "are often better served by both sides going away from a dispute satisfied." 241

151 But the conditions this departure from an orthodox application of rule of law principles to all circumstances with the observation that the parties' primary concern in some circumstances is "to come to a mutually acceptable resolution." ${ }^{242}$ That might require opting out of the national

${ }^{238}$ David Rivkin "The Impact of International Arbitration on the Rule of Law: The 2012 Clayton Utz/University of Sydney International Arbitration Lecture" 29 Arbitration International 327 at 328.

${ }^{239}$ Rutledge, above $\mathrm{n} 93$, at 37.

${ }^{240} \mathrm{By}$ contrast, it seems that parties may not contract out of the principles of natural justice in some matters: Methanex Motunui Ltd v Spellman [2004] NZLR 95 (HC).

${ }^{241}$ Tamanaha, above n 205, at 121.

${ }^{242}$ At 121. 
courts. But we know that the outcome better serves their interests because they have voluntarily chosen the process.

152 So far as an institution has powers that are supported by coercive force, it is essential that that institution be subject to the rule of law, so as to protect the dignity of those living within under that institution. ${ }^{243}$ More specifically, the rule of law is a principle regulating the use of coercive force - it is a "prescription for government". ${ }^{244}$ So far as a BAT tribunal possess coercive power, it ought to be subject to the rule of law.

\section{Constitutional consequences}

153 The rule of law entails a reciprocal obligation among the arms of government to not impose upon the legitimate functions of one another. A proceduralist approach to the rule of law identifies institutional integrity as being essential to the rule of law, and that it is violated where the institutions that uphold procedural protections are "interfered with". ${ }^{245}$ Elias CJ expressed this principle in relation to the courts' obligations to the other branches:

The courts are themselves subject to the rule of law and accordingly cannot usurp powers lawfully exercised by other agencies, including Parliament. ${ }^{246}$

154 Similarly, the rule of law could be said to preclude Parliament and the executive from pursuing policies that undermine the powers of the courts. A removal of access to the courts might amount to an affront the rule of law requiring judicial intervention. $^{247}$ The courts, being a reactionary rather than proactive institution, ${ }^{248}$ are fundamentally reliant on their inherent jurisdiction in order to exercise their constitutional

\footnotetext{
${ }^{243}$ See generally the discussion of jury waivers in relation to arbitration in Rutledge, above n 93, at 157 et seq.

244 Joseph, above n 51, at 153.

${ }^{245}$ Waldron "The Concept and the Rule of Law", above n 61, at 7.

${ }^{246}$ Elias, above n 135, at 19.

247 Philip A Joseph "The Rule of Law: Foundational Norm" in Richard Ekins (ed) Modern Challenges to the Rule of Law (LexisNexis, Wellington, 2011) 47 at 74. Joseph is, however, referring to extreme cases.

248 Richard C Reuben "Democracy and Dispute Resolution: The Problem of Arbitration" (2004) 67 Law and Contemporary Problems 279 at 298.
} 
function. To confine the reach of the jurisdiction is to undermine the judiciary's power.

155 The Diceyan conception of Westminster constitutions considers the central tenet of the rule of law to be the ability of the law to control the actions of government officials. ${ }^{249} \mathrm{We}$ can conceive of the existence and autonomy of the judiciary as being essential to Tamanaha's first theme of the rule of law: that of setting limitations on government. "[T]he essential prerequisite" of the maintenance of the rule of law "is that the judiciary must possess a degree of independence from the rest of the governmental apparatus." ${ }^{250}$ So far as the legislative and executive branches are able to excise portions of the courts' jurisdiction, that threshold is crossed, even if the matter does not directly pertain to an action of the government. But in any case, the actions of BAT tribunals would be an exercise of State power. ${ }^{251}$

156 The rule of law may therefore limit the powers of the executive and legislature to fundamentally adjust the jurisdiction of the courts. Joseph describes the rule of law provision in the Supreme Court Act 2003 as internalising an "unresolved tension", because it simultaneously expresses commitment to the rule of law and to Parliamentary sovereignty-concepts which pull in opposite directions. ${ }^{252}$ Because the rule of law is an a priori concept - that is, one that precedes or is "anterior to" the positive laws made by the State-Joseph claims that the statute establishing the Supreme Court could not change the fundamentals of the constitution. ${ }^{253}$

157 If the rule of law is accepted as a precondition of Parliament's law-making powers, it might be beyond the authority of Parliament to implement the BAT. This conception of lawmaking authority is similar to that expressed by the Chief Justice, where she described: ${ }^{254}$

a more modest principle of legislative primacy under which the legislation of Parliament prevails

\footnotetext{
249 Tamanaha, above n 205, at 117.

${ }^{250}$ At 117.

${ }^{251}$ See above at [107]-[109].

${ }^{252}$ Joseph, above n 51, at 163.

${ }^{253}$ At 163 .

${ }^{254}$ Elias, above n 135 , at 7.
} 
over the decisions of the courts or of subordinate lawmakers unless contrary to the constitutional rules upon which law-making validity depends.

158 It is not clear that the BAT would be seen as sufficient infringement upon the rule of law and access to the courts that the courts would exercise a potential "in extremis power" to disapply legislation. ${ }^{255}$ It is not as though the BAT would disestablish the courts.

159 But in any case the question is pertinent. Judicial independence and the role of law are maintained not simply through de jure institutional arrangements, but the de facto attitudes of other branches of government towards the judiciary, particularly the view "that it is improper to meddle with the judiciary as it fulfils its role interpreting and applying the law."256 Accordingly, the implication of this section can be phrased as a normative call to the legislative and executive organs of State to not act to curtail the courts' jurisdiction.

\section{Privatisation of State function}

160 Some State functions, such as the allocation of punishment, are arguably a non-delegable function of the State. ${ }^{257}$ This argument relies once more on particular conceptions of the nature of the State, described above in the terms of institutional morality. The argument of this part is that there is a limit on the extent to which the State may abandon powers that are justifiable only because they are exercised by the State, rather than other entities.

161 The judiciary is, the author suggests, one of those central functions. Lord Bingham observed, while attempting to articulate the content of the rule of law, that "the provision of courts as one of the essential functions of a liberal democratic State." 258

\footnotetext{
${ }^{255}$ Concerning the potential power, see Joseph, above n 51, at [7.3.2].

${ }^{256}$ Tamanaha, above n 205, at 124.

${ }^{257}$ See, concerning the prison system, Jane Maltby "The Role of the State in Ensuring the Protection of Human Rights in Privately Managed Prisons" (LLB (Hons) Research Essay, Victoria University of Wellington, 2011) at 79. ${ }^{258}$ Bingham, above n 74, at 78 .
} 
162 Many States have, however, in recent decades "embraced such private dispute resolution models as appropriate for a wide array of conflicts." 259 The emergence of arbitration and alternative dispute resolution more generally has challenged the role of the courts as the sole venue for the determination of rights and obligations. This trend forms a part of a larger change in approach to governance, that being "the privatisation of public processes, the diminution of transparency, and the decline of regulation." 260

163 Genn argues that the trend in privatisation is part of a broader process of reconceptualising government functions as services, rather than necessary functions. In relation to the judiciary, once it "is packaged as a public service as opposed to an arm of government it becomes necessary for it to justify its claim to resources."261 This transition is part of a broader discourse in which civil justice is "locate[d] ... as a private matter rather than a public and socially important good." $" 262$

164 The trend toward privatisation risks the institutional capacity of the courts. Sufficient resources are necessary for the judicial to continue to discharge its broader constitutional function of providing a check on the actions of government.

165 In a similar vein, a reason for retaining cases in State courts is that cases build judicial capacity in the form of the experience of the judges. The more commercial disputes that are adjudicated before New Zealand courts, the better the ability of the judiciary to effectively adjudicate them. The first benefit of this is that such capacity is important for domestic commercial relations. Similar issues present themselves in international commercial disputes and domestic commercial disputes, and the adjudication of the former increases the quality of the adjudication of the latter. There is a desirable crosssubsidisation of commercial dispute resolution when cases that would otherwise be diverted by the BAT are kept in New Zealand courts.

\footnotetext{
${ }^{259}$ Judith Resnik "For Owen M. Fiss: Some Reflections on the Triumph and the Death of Adjudication" (2003) 58 U Miami L Rev 173 at 191.

260 At 191.

261 Genn, above n 9, at 47.

262 Genn, above n 9, at 26.
} 
166 As regards the efficacy of arbitration, it cannot flourish without strong State courts, both as guides for the inevitable interpretation of matters of domestic law, and as assistants in the task of effective arbitration-enforceable interim measures and a judiciary willing to enforce arbitral awards is essential to functioning arbitration. ${ }^{263}$

167 Moreover, the judiciary provides a public good. The law promulgated by the judiciary allows for the functioning of inter alia economic relations without the need to formally adjudicate each possible dispute. Disputes are often resolved in the shadow of the law. But for "civil justice to perform its public role-to cast its shadow-adjudication and public promulgation of decisions are critical." 264 That is a public good because it is non-rivalrous, in that consumption of the law does not exhaust the resource, and it can be consumed without paying for its production or access to it. Accordingly, we can expect a private market to underprovide it. ${ }^{265}$

168 A final line of argument against the privatisation of the judicial function is based on the justification for coercive force. This form of argumentation has been used in the criticism of the privatisation of prisons. Medina describes the reasoning thus: 266

a private entity employing governmental powers poses an un- avoidable risk of an unjustified use of force. According to this view, the very "culture" of for-profit organizations creates a risk of an abuse of power.

169 These arguments have more rhetorical force in the case of prisoners because of their vulnerability. The reasoning sits less well with regard to commercial parties which do not experience the power imbalances that prisoners do.

\footnotetext{
263 See generally Jan Paulsson "Why Good Arbitration Cannot Compensate for Bad Courts" (2013) 30 Journal of International Arbitration 345.

${ }^{264}$ Genn, above $\mathrm{n} 9$, at 21.

265 Genn, above n 9, at 47, n 28. The obvious caveat in relation to law is that, while publically available, it generally requires the purchase of professional services to access it.

266 Barak Medina "Constitutional limits to privatization: The Israeli Supreme Court decision to invalidate prison privatization" (2010) 8 Int Jnl of Constitutional Law 690 at 691.
} 
170 The arguments against the BAT on the grounds that it is a privatisation of an essential State function are not, in the author's view, dispositive. Each largely turns on empirical assumptions about the magnitude of the effect of the BAT which are difficult to determine ex ante. These are more useful then as part of a holistic assessment of the constitutionality of the BAT.

\section{Open justice and democracy}

171 This Part addresses the impact of the BAT on the constitutional norms of open justice and democracy. They are grouped together here, because they are both, the author suggests, norms of accountability. For intstance, the House of Representatives must generally conduct its business in public for the reason that the public must be privy to its activities in order to hold it accountable. Similar though not identical principles apply to adjudication. ${ }^{267}$

\section{A Openness and accountability}

172 It has long been recognised that administering justice in public is a part of a Westminster constitution and was described in 1913 as "a sound and very sacred part of the constitution of the country and the administration of justice." ${ }^{268}$ It is a principle of "ancient vintage" that appears in a range of constitutional and human rights documents internationally, ${ }^{269}$ and has been described as a fundamental constitutional principle in New Zealand. ${ }^{270}$ Jeremy Bentham said of publicity that publicity: 271

is the very soul of justice. It is the keenest spur to exertion, and the surest of all guards against improbity. It keeps the judge himself, while trying, under trial.

\footnotetext{
267 Joseph Jaconelli Open Justice: A Critique of the Public Trial (Oxford University Press, Oxford, 2002) at 2.

${ }^{268}$ Scott $v$ Scott [1913] AC 417 at 473 per Lord Shaw.

${ }^{269}$ Jaconelli, above $\mathrm{n} 267$, at 5.

${ }^{270}$ Joseph, above n 51, at [15.7.3].

271 Jeremy Bentham Benthamiana or Select Extracts from the Works of Jeremy Bentham (1843) at 115, cited in New Zealand Law Commission Improving the Arbitration Act 1996 (NZLC R83, 2003) at [76].
} 
173 Admittedly, the principle of open justice generally gives way to the principle of party autonomy in respect of arbitration. ${ }^{272}$ Even then, the Law Commission observed that arbitrations where a State-owned enterprise was a party and matters of public concern were at issue ought to be public, as well as "information derived from an arbitration which is relevant to the regulatory functions of the New Zealand Stock Exchange". ${ }^{273}$ Privacy and confidentiality in arbitration are not, then, absolute rights of the parties. In any case, the rationale for that departure stems from the consent of the parties, which is absent in the case of BAT arbitration.

174 The cornerstones of democratic systems are participation of those governed, and the accountability of those who govern. ${ }^{274}$ The exercise of coercive State force is justifiable so far as those subject to it are involved in deciding the grounds on which it is exercised. When members of the public find State actions, including judicial decisions, contrary to their values, a system of democratic participation allows them to hold institutions accountable. $^{275}$ This principle of accountability is bound up with the rule of law. Thus Waldron observes that participation is important to the maintenance of the rule of law: ${ }^{276}$

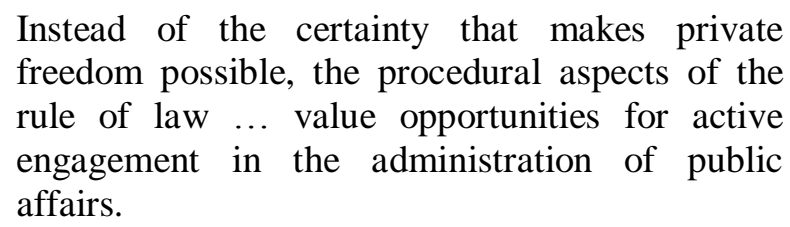

175 The judiciary, though not immediately electorally accountable, are a part of the fabric of representative democracy. Judges, even when appointed, are selected for their conformity with views of the community. They do not live in isolation from the views of the community at large, and their work is subject to sometimes strident public criticism which cannot but influence their decision-making. ${ }^{277}$

\footnotetext{
${ }^{272}$ New Zealand Law Commission Improving the Arbitration Act 1996 (NZLC R83, 2003) at [46].

${ }^{273}$ At [46].

${ }^{274}$ Reuben, above $\mathrm{n} 248$, at 287-8.

275 At 290.

${ }^{276}$ Waldron "The Concept and the Rule of Law", above n 61, at 8.

${ }^{277}$ Consider the response of the press to the decision of the Court of Appeal in Attorney-General v Ngati Apa [2003] 3 NZLR 643: Editorial "Stealthy
} 
176 Accordingly, the judiciary and the other branches are "partners in the common endeavour of representative government." ${ }^{278}$ In the case of court, in absence of elections to office, the princpal means of accountability is through public access to proceedings and reasons. ${ }^{279}$ The three purposes for giving reasons have been identified by the Court of Appeal as being (i) openness in the administration of justice, (ii) permitting decision-makers charged with reviewing a decision to understand the reasons, and (iii) that it is a form of discipline that is "the best protection against wrong or arbitrary decisions and inconsistent delivery of justice." ${ }^{280}$ Further, publicity of adjudication ensures that legislatures can "monitor the enforcement of public law and amend legislation when judicial decisions go awry."281 The end of all of those is the promotion of accountability.

177 But the private and confidential nature of BAT arbitration severs the public from the institution. Passing off a substantial volume of the decision-making to private institutions is prima facie inconsistent with the democratic justification for the authority of the decision-maker to interpret and apply the law. Arbitration diminishes public participation in the administration of justice. ${ }^{282}$

Unlike State courts which, except in unusual circumstances, ${ }^{283}$ are open to the public and publish their reasoning, arbitral tribunals generally sit in private and their decisions are subject to confidentiality obligations. Therefore "arbitration tends to be undemocratic, especially when compelled," 284 because it decreases public participation in the adjudicative process. The tribunal is required, unless the parties have agreed otherwise, to State the reasons for its decision. ${ }^{285}$ But some courts have

treaty extension had to be blocked" The New Zealand Herald (New Zealand, 25 June 2003).

${ }^{278}$ Norman Redlick "Judges as Instruments of Democracy" in Shimon Shetreet (ed) The Role of Courts in Society (Martinus Nijhoff Publishers, The Netherlands, 1988) 149 at 156.

${ }^{279}$ Lewis v Wilson \& Horton Ltd [2000] 3 NZLR 546, (2000) 6 HRNZ 1 at [79].

${ }^{280}$ At [79]-[82].

${ }^{281}$ Adriaan Lanni "Protecting public rights in private arbitration" (1998) 107

Yale Law Journal 1157 at 1161.

${ }^{282}$ Reuben, above n 248, at 299.

${ }^{283}$ See, for example, Criminal Procedure Act 2011, ss 197-199.

${ }^{284}$ Reuben, above n 248, at 295.

${ }^{285}$ UNCITRAL Arbitration Rules, art 34(3). 
enforced awards that lacked reasons even where that lack was contrary to both the arbitration agreement and the procedural law of the arbitration. ${ }^{286}$ The reasons will in any case likely be confidential, $^{287}$ and so unable to fulfil the function of accountability.

178 Arbitral tribunals also lack accountability because opportunities for review of decisions are more circumscribed, ${ }^{288}$ and the public, including the press, the public's main proxy for judicial accountability, does not have access to the arbitral tribunal's hearings, or their decisions.

179 By contrast, Caplan argues that private arbitral institutions operate in a competitive environment and, unlike monopolistic State courts, will accordingly be more accountable to their 'customers' than State courts. ${ }^{289}$ Arbitral institutions are a dispute resolution product which must compete on inter alia the degree of fairness that they provide by way of process protocols. The problem for the BAT is that it preselects an institution, removing the element of competition. ${ }^{290}$ Nonetheless, the appointing authority remains a participant in the market of voluntary arbitration and we can expect competitive pressures to persist. In any case, public accountability is distinct principle to that of natural justice, the main target of Caplan's economic reasoning. Accountability is a duty owed to the public, not the parties to the dispute. We cannot expect parties to pay premiums for the diffuse benefit of public accountability, and the argument for leaving the matter to the market is, then, less persuasive.

180 The overarching concern is that these strands of accountability are necessary for the legitimacy of the existing constitutional order. And it is important that they exist visibly. Interpretation of law, and particularly constitutional law, turns in part on how something looks. Accordingly, the Law Commission observed that "many legal principles rest on a justification that

\footnotetext{
${ }^{286}$ Born International Commercial Arbitration, above n 32, at 2759, n 268.

${ }^{287}$ Unless the parties agree otherwise. Article 4(2).

${ }^{288}$ Reuben, above n 248, at 299.

${ }^{289}$ Caplan and Stringham, above n 93; Rutledge, above n 93, at 151.

290 See, concerning mandatory arbitration and the market, Reuben, above $n$ 248 , at 301 .
} 
appearance can be as important as substance." 291 A recent development in public concern about adjudicative processes is the extent to which the body of adjudicators are representative of the plurality of their communities. ${ }^{292}$ Proportional representation is an important factor in the democratic legitimacy of the judiciary. ${ }^{293}$ It is unlikely, in the author's view, that the arbitrators appointed by the Permanent Court will achieve this democractic objective.

181 More than simply needing to be done, must be manifestly seen to be done. ${ }^{294}$ In this vein, Reuben argues that: ${ }^{295}$

Courts and the law provide for the legitimacy of the political, economic and social order by assuring legal constraints, compliance and stability. This social capital is substantial, but is still capable of diminishment.

182 That social capital is at risk if the structures of accountability that constrain and make justifiable the exercise of State power are undermined. That is the negative argument from open justice. The next section formulates the argument from open justice in the positive sense: there is much to be gained from public adjudication.

\section{B Public interest in particular laws}

183 Decreasing the number of cases that are heard before the courts risks undermining the courts' role of sovereign interpreting the law. ${ }^{296}$ Similarly, it prevents courts from fulfilling their institutional responsibility to develop the law. The first concern historically gave rise to questions of arbitrability, and has waned as arbitration has become more commonplace. The

${ }^{291}$ Law Commission, above n 159, at [1.16].

292 Rod Vaughan "Judicial makeover opens more doors to wannabe Judges" (6 September 2013) Auckland District Law Society Incorporated <www.adlsi.org.nz>; Law Commission, above n 157, at [3.33] and [3.38].

293 See generally Richard Devlin, Wayne A MacKay and Natasha Kim "Reducing the Democratic Deficit: Representation, Diversity and the Canadian Judiciary, or towards a Triple P Judiciary" (2000) 38 Alta L Rev 734 at 789 et seq.

${ }^{294} R$ v Sussex Justices, Ex parte McCarthy [1924] 1 KB 256, [1923] All ER Rep 233; Saxmere Co Ltd v Wool Board Disestablishment Co Ltd [2009] NZSC 72 at [3] per Blanchard J and [60] per McGrath J.

${ }^{295}$ Reuben, above n 248, at 295.

${ }^{296}$ Lord Bridge in X Ltd v Morgan-Gampian Ltd [1991] 1 AC 1 at 48 spoke of the "sovereignty of the Queen's courts in interpreting and applying the law." 
second concern, by contrast, has become more acute with the proliferation of arbitration.

184 Historically, the "arbitrability" of certain areas of law that engage the interests of third parties (the public, for instance) that are not party to the arbitration agreement has been contentious. ${ }^{297}$ In the United States, the judicial approach in recent years has expanded the number of public law matters that can be subject to arbitration, including, for instance, antitrust legislation (or, competition law). ${ }^{298}$ This trend is present in the limited New Zealand case law on the matter. ${ }^{299}$

185 Legislation such as the Commerce Act 1986 contains important public policy, the enforcement of which is for the benefit of the public. ${ }^{300}$ That legislation could be relevant to an international commercial dispute. ${ }^{301}$ The public is not, though, ever party to the arbitration of international commercial disputes. Where the law is misapplied or ignored by a BAT tribunal, the public may suffer, and, as explored above, suffer all the more for the lack of accountability.

186 Secondly in terms of public interest in particular law, the production of precedent is a public good. ${ }^{302}$ Arbitral tribunals may be less capable at developing the law than State courts for the reason that awards are seldom published and proceedings are held in private. Identical disputes can, then, be resolved in materially different ways without any mechanism for correcting the divergent effect of the law. Moving more disputes to arbitration has the consequence, then, of stymying the development of the law.

\footnotetext{
${ }^{297}$ Park, above n 4, at 211.

${ }^{298}$ Mitsubishi Motors Corp v Soler Chrysler-Plymouth Inc 473 US 614 (1985)

${ }^{299}$ See Attorney-General v Mobil Oil NZ Ltd [1989] 2 NZLR 649 (HC) where the Crown's argument that matters relating to the Commerce Act 1986 ought not to be determined by private arbitration were unsuccessful when balanced with the importance of upholding an arbitration agreement. See Williams and Kawharu, above n 13, at 196.

300 States can, though, determine in the BAT what disputes are to be arbitrable or not. See above at fn 17.

301 Commerce Act 1986, s 4(1): "This Act extends to the engaging in conduct outside New Zealand by any person resident or carrying on business in New Zealand to the extent that such conduct affects a market in New Zealand." See generally, Adrienne Wing "Catching foreign nationalsa question of statutory interpretation" [2010] CSLB 69(6), and Poynter v Commerce Commission [2010] NZSC 38, [2010] 3 NZLR 300.

${ }^{302}$ See above at [167].
} 
187 This is of particular concern in areas of law that are still developing. In the context of insurance law arbitrations, Abraham and Montgomery argue that unique provisions in contracts may never fall to be interpreted by the courts, preventing the development of precedent. ${ }^{303}$ With emerging areas of regulation in international commercial relations such as attempts to control greenhouse gas emissions, it might be undesirable to discourage the development of public precedent on the proper interpretation of contracts operating in regulated contexts.

188 These concerns cannot, however, be decisive in determining the constitutionality of the BAT. Because it is already considered permissible for parties to contract into arbitration, and because such contracts have the above described effect on the administration and development of the law, the effect of the BAT can only be a matter of degree. The decision in AttorneyGeneral v Mobil Oil NZ Ltd indicates that preservation of the arbitration agreement outweighs the importance of the courts managing the application of high-importance laws. ${ }^{304}$ The lack of consent in BAT arbitration may, however, lead to these questions being considered in a different light. The arguments remain, but are reduced the status of a cost to be weighed against the purported benefits of the BAT.

\section{Autonomy}

189 Protecting the autonomy of persons, a core value of democratic communities, might require that the default position be State courts, and that arbitration can only proceed by express consent. Reuben makes this argument in the context of consumer arbitration in the US, on the grounds that arbitration is often unilaterally imposed. ${ }^{305}$ Resorting to general principles of contract law - a field of law deeply focussed on values of autonomy - it might be preferable to place the transaction cost of negotiating arbitration on the repeat player who desires to arbitrate, given that most parties will assume that the State

\footnotetext{
${ }^{303}$ Abraham and Montgomery, above n 219, at 363.

${ }^{304}$ Attorney-General v Mobil Oil NZ Ltd [1989] 2 NZLR 649 (HC).

${ }^{305}$ Reuben, above n 248, at 299.
} 
courts are the default option. Freedom of contract, Barnett contends, entails both: ${ }^{306}$

both freedom to contract - the power to effect one's legal relations by consent —and freedom from contract - the immunity from having one's rights to resources transferred without one's consent.

190 Certainly, when chosen by the parties, arbitration enhances democratic values, such as autonomy. ${ }^{307}$ But the BAT would be in effect creating a standard term for contracts of the relevant category. To the extent that that is inconsistent with the parties intent, they have gained rather than lost autonomy. ${ }^{308}$

191 One of the juridical rationales for the freedom of contract is that generally speaking individuals and associations that they might freely form have a comparative advantage regarding "personal" and "local" knowledge over a central planning entity. ${ }^{309}$ The implication of this observation is that there should be a presumption in favour of allowing private agreements to produce and regulate relationships between individuals, or at least a facility of that kind.

192 Some forms of standardised terms, such as those based upon custom, can be explained as implied-in-fact terms, in that some implied terms "properly understood as part of the 'objective' or 'public' meaning" of a particular kind of agreement, and those terms implied by operation of statute or judicial precedent are generally the product of those customs. ${ }^{310}$

193 But even ardent supporters of theories of fictionalised consent in relation to default rules temper the philosophical awkwardness of the approach by reference to common understandings in particular communities. Consent may be

\footnotetext{
${ }^{306}$ Barnett, above n 14, at 828. Emphasis in original.

307 Reuben, above n 248, at 295. See also, concerning libertarian and anarchist theories of legal pluralism, Bryan Caplan and Stringham, above $n$ 93, at 506-7.

${ }^{308}$ Sternlight above $\mathrm{n} 220$, at 1672 .

${ }^{309}$ Barnett, above n 14, at 838-9. See also Paulsson, above n 39, at 2.

${ }^{310}$ Stephen A Smith Contract Theory (Oxford University Press, New York, 2004) at 309.
} 
manifested in silence in circumstances where parties had reason to know of the default rule that would be imposed. ${ }^{311}$

194 Accordingly, “... when one-shot players are contracting with each other or with repeat players, the default rule should reflect ... everyday common sense and the onus should fall upon the repeat player to contract around the rule." 312 This encourages the repeat player to educate others, and brings the subsequent contractual relationship hews closer to the subjective intentions of the parties. ${ }^{313}$

195 So in a choice between the default rule that disputes be subject to the jurisdiction of State courts, and another, that disputes be subject to BAT arbitration, the choice ought comport with the common understanding of how disputes arising from the relationship are to be resolved. This might suggest that we prefer a default rule of State courts in order to maximise the autonomy of citizens.

\section{Conclusion}

196 It should be kept in mind that "the law of arbitration is written on the basis that the parties have consented to that method of decision-making." 314 Compulsory jurisdiction is a sovereign power which ought to only be exercised within a system that has developed to contain and moderate the use of that power. When viewed holistically, the effect of the BAT on the constitutional principles discussed in this paper is, in the author's view, too great a modification to the existing constitutional order without better evidence that the policy would be effective.

197 The law does not, however, exist to serve the law. The law exists to serve people. Constitutional principles are not to be preserved for their own sake. They are to be modified to meet the needs of the time. The adaptability of the unwritten

311 Barnett, above $\mathrm{n} \mathrm{14}$; with the caveat that as transaction costs of discovering the default rule increase, the strength of the inference decreases. ${ }^{312}$ At 892.

313 At 892.

${ }^{314}$ Law Commission, above n 40, at 100. 
constitution facilitates such progress. Indeed, such reflects what Burke called "the genius of the Constitution". 315

198 The BAT could be constitutionally permissible, then, in circumstances where the benefits were suitably clear, and the harms to the constitution were tempered by some modifications to the policy. Accordingly, the author suggests the following changes.

199 First, the courts should be more willing to supervise BAT arbitrations than consensual arbitration. This will come at the expense of some of the efficiency gains of the BAT, but it is necessary to avoid too great an injury to the separation of powers the maintenance of the rule of law. Possible areas for expanded review would be a change of approach to the meaning of 'public policy' and non-arbitrability as grounds for refusing enforcement. Closer review on matters where the interests of the public at large are engaged would minimise constitutional concerns. Likewise, the courts might take a stronger approach to the matter of excess of jurisdiction. At the very least, the presumption that the arbitrator's assessment of jurisdiction be undisturbed must be abandoned to protect the rule of law.

200 Second, BAT arbitrations should be held in public unless the parties agree to the contrary. There exists provision for private hearings already, both in State courts and arbitral tribunals. But the transaction cost of making hearings private should fall on those who desire privacy, rather than on those who desire publicity, given the broad public interest in open justice.

201 Third, the tribunals should either publish reasons for their decision, or there should be established some mechanism for the publication of digests of decisions, or anonymised decisions. The availability of decisions would allow a larger measure of accountability, and the eventual empircal assessment of the success of the policy. It would therefore temper some of the rule of law and open justice concerns.

202 These concerns raised in this paper may be less rhetorically pressing given that the subject matter is international

${ }^{315}$ Joseph, above n 51, at [1.2]. 
commercial disputes. Indeed, Sternlight makes light of the public interest elements of such disputes, observing that constitutional concerns are amplified: ${ }^{316}$

when the subjects handled in arbitration affect public interests. That is, we care more when federal statutory claims such as employment discrimination are taken away from the public eye than when a dispute over the quality of soybeans shipped from Missouri to Nevada is handled privately.

203 But the magnitude of the effect of the BAT on the arrangement of the civil justice system and the constitutional order demands close attention, even if it at first seems simply a question of efficiency. The risk of these policies is that, as Elias CJ observed in the abstract, "laws and practices may chip away at both access to the courts and their independence without any conscious design." 317 Such a modification to the constitutional arrangement requires careful consideration.

${ }^{316}$ Sternlight, above n 220, at 1665 .

${ }^{317}$ Elias, above n 50, at 8. 


\section{Bibliography}

A Cases

$1 \quad$ New Zealand

Ali v Deportation Review Tribunal [1997] NZAR 208 (HC).

Arbitrators Institute of New Zealand Inc $v$ Legal Services Board [1995] 2 NZLR 202 (HC).

Attorney-General v Mobil Oil NZ Ltd [1989] 2 NZLR 649 (HC).

Attorney-General v Reid [2000] 2 NZLR 377 (HC).

Bulk Gas Users Group v Attorney-General [1983] NZLR 129.

Burt v Govenor-General [1992] 3 NZLR 672 (CA).

Carter Holt Harvey Ltd v Genesis Power Ltd [2006] 3 NZLR 794 (HC).

Chisholm v Auckland City Council (CA 32/02, 29 November 2002).

Claydon v Attorney-General [2004] NZAR 16 (CA).

Fitzgerald v Muldoon [1976] 2 NZLR 615 (SC).

Gold and Resource Developments (NZ) Ltd v Doug Hood Ltd [2000] 3 NZLR 318 (CA).

Hansen v R [2007] NZSC 7, [2007] 3 NZLR 1.

Lal v Removal Review Authority HC Wellington AP95/92, 10 March 1994.

Mangawhai Ratepayers' and Residents' Association Inc $v$ Kaipara District Council [2014] NZHC 1147.

Matthews v Marlborough District Council [2000] NZRMA 451 (HC).

Methanex Motunui Ltd v Spellman [2004] NZLR 95 (HC).

Ministry of Transport v Noort [1992] 3 NZLR 260 (CA).

New Zealand Drivers' Association $v$ New Zealand Road Carriers [1982] 1 NZLR 374 (CA). 
New Zealand Waterside Workers' Federation Industrial Assoc of Workers v Frazer [1924] NZLR 689 (SC).

O'Regan v Lousich [1995] 2 NZLR 620 (CA).

Peters v Davison [1999] 2 NZLR 164 (CA).

Police v Sharmly (No 1) [1999] DCR 1186 (DC).

Pomeroy v Police [2000] NZAR 273, (1999) 5 HRNZ 405 (HC).

Poynter v Commerce Commission [2010] NZSC 38, [2010] 3 NZLR 300.

Savril Contractors Ltd v Bank of New Zealand [2002] NZAR 699 (HC).

Saxmere Co Ltd v Wool Board Disestablishment Co Ltd [2009] NZSC 72.

Taito v R [2003] 3 NZLR 577 (PC).

Tangiora v Wellington District Legal Service Committee [2000] 1 NZLR 17 (PC).

Todd Petroleum Mining Co Ltd v Shell (Petroleum Mining) Co Ltd HC Wellington CIV-2008-485-2816, 17 July 2009.

Unitech University of Technology $v$ Attorney-General HC Wellington CIV 2005-485-89, 7 July 2005.

Westco Lagan v Attorney-General [2001] 1 NZLR 40 (HC).

Wool Board Disestablishment Co Ltd v Saxmere Co Ltd [2010] NZCA 513, [2011] 2 NZLR 442.

Young v Police [2007] 2 NZLR 382 (HC).

Zaoui v Attorney-General [2005] 1 NZLR 577 (SC).

2 United States

CFTC v Schor (1986) 478 US 883.

Hall Street Associates LLC v Mattel Inc (2008) 552 US 576.

Lisanti v Alamor Title Ins of Texas (2002) 55 P3d 962 (NM).

Mitsubishi Motors Corp v Soler Chrysler-Plymouth Inc (1985) 473 US 614. 
Parsons \& Whittlemore Overseas Co v Societe Generale de L'Industrie du Papier (RAKTA) (1974) 508 F2d 969 (2nd Cir).

\section{United Kingdom}

Albon v Naza Motor Trading Sdn Bhd [2007] EWCA Civ 1124. Anisminic Ltd v Foreign Compensation Commission [1969] 2 AC 147 (HL).

Attorney General v British Broadcasting Corporation [1980] 3 All ER 161 (HL).

Bremer Vulkan Schiffbau Und Maschinenfabrik v South India Shipping Corporation Ltd [1981] AC 909 (HL).

Fiona Trust \& Holding Corp v Privalov [2007] 1 All ER (Comm) 891.

Jivraj v Hashwani [2011] UKSC 40, [2011] WLR 1872.

$R$ (Jackson) v Attorney General [2005] UKHL 56, [2006] 1 AC 262.

$R v$ Medical Appeal Tribunal, Ex parte Gilmore [1957] 1 QB 574.

$R$ v Sussex Justices, Ex parte McCarthy [1924] 1 KB 256, [1923] All ER Rep 233.

Reg $v$ National Joint Council for the Craft of Dental Technicians (Disputes Committee), Ex parte Neate [1953] 1 QB 704.

Scott v Scott [1913] AC 417

Whitlam, $R$ (on the application of) $v$ Lord Chancellor [1997] EWHC Admin 237.

X Ltd v Morgan-Gampian Ltd [1991] 1 AC 1.

4 European Court of Human Rights

Sunday Times v United Kingdom (1979) 2 EHRR 245.

B Legislation

$1 \quad$ New Zealand

Arbitration Act 1996. 
Criminal Procedure Act 2011.

Commerce Act 1986.

Judicature Act 1908.

New Zealand Bill of Rights Act 1990.

Supreme Court Act 2003.

2 Singapore

Arbitration Act 2001.

\section{Journal articles}

Adriaan Lanni "Protecting public rights in private arbitration" (1998) 107 Yale Law Journal 1157.

Adrienne Wing "Catching foreign nationals - a question of statutory interpretation" (2010) CSLB 69(6).

Barak Medina "Constitutional limits to privatization: The Israeli Supreme Court decision to invalidate prison privatization" (2010) 8 Int Jnl of Constitutional Law 690.

Bernard Hanotiau "Consent to Arbitration: Do We Share a Common Vision?” (2011) 27 Arbitration International 539.

Bryan Caplan and Edward P Stringham "Privatising the Adjudication of Disputes" (2008) 9 Theoretical Enquiries in Law 503.

Catherine A Rogers "Fit and Function in Legal Ethics: Developing a Code of Conduct for International Arbitration" (2001) 23 Mich J Intl L 341.

David A R Williams "Arbitration and Dispute Resolution" (2005) NZ L Rev 119.

David Rivkin "The Impact of International Arbitration on the Rule of Law: The 2012 Clayton Utz/University of Sydney International Arbitration Lecture" 29 Arbitration International 327.

Douglas E Edlin "A Constitutional Right to Judicial Review: Access to Courts and Ouster Clauses in England and the United States" (2009) 57 The American Journal of Comparative Law 67. 
Duarte Gorjão Henriques "Dealing with the "Buts" of "BATs" Within the Portugese Jurisdiction" (2014) 13 YAR.

Eduardo J Couture "The Nature of the Judicial Process" (1950) 25 Tulane Law Review 1.

Gary Born "BITs, BATs and Buts: Reflections on International Dispute Resolution" (2014) 13 YAR.

Jan Paulsson "Why Good Arbitration Cannot Compensate for Bad Courts" (2013) 30 Journal of International Arbitration 345.

Jean R Sternlight "Creeping Mandatory Arbitration: Is It Just?" (2004) 57 Stanford L Rev 1631.

John Priestley “Chipping Away at the Judicial Arm?” (2009) 17 Waikato Law Review: Taumauri 1.

Judith Resnik "For Owen M. Fiss: Some Reflections on the Triumph and the Death of Adjudication" (2003) 58 U Miami L Rev 173.

Kenneth S Abraham and J W Montgomery "The Lawlessness of Arbitration" (2002) 9 Conn Ins LJ 355.

Lord Bingham "The Rule of Law” (2007) 66 CLJ 67.

Lord Woolf "The Rule of Law and a Change in the Constitution" (2004) 63 CLJ 317.

Matthew Palmer "New Zealand Constitutional Culture" (2007) 22 NZULR 565.

Petra Butler and Campbell Herbert "Access to Justice vs Access to Justice for Small and Medium Enterprises: The Case for a Bilateral Arbitration Treaty" (2014) NZJPIL (forthcoming).

Randy E Barnett "The Sound of Silence: Default Rules and Contractual Consent” (1992) 78 Virginia Law Review 886.

Richard C Reuben "Democracy and Dispute Resolution: The Problem of Arbitration" (2004) 67 Law and Contemporary Problems 279.

Richard Devlin, Wayne A MacKay and Natasha Kim "Reducing the Democratic Deficit: Representation, Diversity 
and the Canadian Judiciary, or towards a Triple P Judiciary" (2000) 38 Alta L Rev 734.

Richard $\mathrm{H}$ Fallon of Legislative Courts, Administrative Agencies and Article III (1988) 101 Harv L Rev 915.

Robin Cooke "Fundamentals" (1988) NZLJ 158.

S A de Smith "Statutory Restriction of Judicial Review" (1955) 18 MLR 575.

Sian Elias "Administrative Law for "Living People"” (2009) 68 CLJ 47.

Sian Elias "Fundamentals: A Constitutional Conversation" (2011) 19 Waikato Law Review: Taumauri 1.

D Books and chapters in books

Andrea Marco Steingruber Consent in International Arbitration (Oxford University Press, New York, 2012)

Andrew Butler and Petra Butler The New Zealand Bill of Rights Act: A Commentary (LexisNexis, Wellington, 2005).

Anthony $\mathrm{H}$ Angelo Constitutional Law in New Zealand (Kluwer Law International, The Netherlands, 2011).

Brian Z Tamanaha On the Rule of Law: History, Politics, Theory (Cambridge University Press, Cambridge, 2004).

Cabinet Office Cabinet Manual 2008.

Campbell McLachlan, Laurence Shore and Matthew Weiniger International Investment Arbitration: Substantive Principles (Oxford University Press, Oxford, 2008).

David A R Williams and Amokura Kawharu Williams \& Kawharu on Arbitration (LexisNexis, Wellington, 2011).

Emmanuel Gaillard and John Savage (eds) Fouchard, Gaillard, Goldman on International Commercial Arbitration (Kluwer International Law, The Hague, 1999).

Emmanuel Gaillard Legal Theory of International Arbitration (Martinus Nijhoff Publishers, The Netherlands, 2010).

Gary Born International Arbitration: Law and Practice (Kluwer International Law, The Netherlands, 2012). 
Gary Born International Commercial Arbitration (Kluwer International Law, The Netherlands, 2009).

Gary Born International Commercial Arbitration: Volume I (2nd ed, Kluwer International Law, The Netherlands, 2014).

Geoffrey Palmer "The Legal Framework of the Constitution" in Colin James (ed) Building the Constitution (Institute of Policy Studies, Victoria University of Wellington, Wellington, 2000) 182.

Geoffrey Palmer and Matthew Palmer Bridled Power: New Zealand's Constitution and Government (4th ed, Oxford University Press, Melbourne, 2004).

Hazel Genn Judging Civil Justice (Cambridge University Press, Cambridge, 2010).

HLA Hart The Concept of Law (3rd ed, Oxford University Press, Oxford, 2012).

J D Heydon "What Do We Mean By the Rule of Law?" in Richard Ekins (ed) Modern Challenges to the Rule of Law (LexisNexis, Wellington, 2011) 15.

Jan Paulsson The Idea of Arbitration (Oxford University Press, Oxford, 2013).

Jeremy Waldron "Principles of Legislation" in Richard W Bauman and Tsvi Kahana (eds) The Least Examined Branch: The Role of the Legislature in the Constitutional State (Cambridge University Press, 2006) 15.

Joseph Jaconelli Open Justice: A Critique of the Public Trial (Oxford University Press, Oxford, 2002).

Joseph Raz The Authority of Law: Essays on Law and Morality (Oxford University Press, Oxford, 1979).

K J Scott The New Zealand Constitution (Oxford University Press, London, 1962).

Nigel Blackaby and others Redfern and Hunter on International Arbitration (5th ed, Oxford University Press, Oxford, 2009). 
Norman Redlick "Judges as Instruments of Democracy" in Shimon Shetreet (ed) The Role of Courts in Society (Martinus Nijhoff Publishers, The Netherlands, 1988) 149.

Paul Rishworth et al The New Zealand Bill of Rights (Oxford University Press, Auckland, 2003)

Peter B Rutledge Arbitration and the Constitution (Cambridge University Press, New York, 2013).

Peter Hennessy Cabinet (Basil Blackwell, Oxford, 1986).

Philip A Joseph Constitutional and Administrative Law in New Zealand (4th ed, Brookers, Wellington, 2014).

Roger Masterman The Separation of Powers in the Contemporary Constitution: Judicial Competence and Independence in the United Kingdom (Cambridge University Press, Cambridge, 2010).

Ronald Dworkin Law's Empire (Fontana Press, London, 1986).

S E Finer, Vernon Bogdanor and Bernard Rudden Comparing Constitutions (Oxford University Press, Oxford, 1995).

Stavros L Brekoulakis Third Parties in International Commercial Arbitration (Oxford University Press, Oxford, 2010).

Stephen A Smith Contract Theory (Oxford University Press, New York, 2004).

William W Park Arbitration of International Business Disputes: Studies in Law and Practice (2nd ed, Oxford University Press, New York, 2012).

E Papers and reports

Geoffrey Palmer "A Bill of Rights for New Zealand: A White Paper” [1984-1985] I AJHR A6.

Helen Winkelmann "ADR and the Civil Justice System” (paper presented to Taking Charge of the Future AMINZ Conference, August 2011).

Jane Maltby "The Role of the State in Ensuring the Protection of Human Rights in Privately Managed Prisons" (LLB (Hons) Research Essay, Victoria University of Wellington, 2011) 
Jeremy Waldron "The Concept and the Rule of Law" (Working Paper No. 08-50, Public Law \& Legal Theory Research Paper Series, New York University School of Law).

Law Commission Arbitration (NZLC, R20, October 1991).

Law Commission Review of the Judicature Act 1908: Towards a Consolidated Courts Act (NZLC IP29, 2012).

Law Commission Review of the Judicature Act 1908: Towards a New Courts Act (NZLC R126, 2012).

Matthew Palmer "Legislative Constitutionalism Ascendant? Who Interprets an Unwritten Constitution in New Zealand?" (paper presented to Conference on Legislatures and Constitutionalism: The Role of Legislatures in the Constitutional State, Centre for Constitutional Studies, Alberta, July 2004).

Matthew Palmer "The Place of the Judiciary in the Constitutional Culture of New Zealand" (Paper presented to the Symposium on Australasian Constitutionalism, Centre for Comparative Constitutional Studies, University of Melbourne Law School, December 2013)

Ministry of Justice Annual Report 1 July 2010 - 30 June 2011 <www.justice.govt.nz>.

Law Commission Improving the Arbitration Act 1996 (NZLC R83, 2003).

Sian Elias "Sovereignty in the 21st Century: Another Spin on the Merry-Go-Round" (address to conference on Sovereignty in the 21st Century, Institute for Comparative and International Law, University of Melbourne, March 2003).

United Kingdom Select Committee on the Constitution Relations between the executive, the judiciary and Parliament (HL) (2006-07) HL 151.

\section{$F \quad$ Internet materials and other}

Editorial "Stealthy treaty extension had to be blocked" The New Zealand Herald (New Zealand, 25 June 2003). 
Ministry of Justice The Guidelines on the New Zealand Bill of Rights Act 1990: A Guide to the Rights and Freedoms in the Bill of Rights Act for the Public Sector <www.justice.govt.nz>.

Rod Vaughan "Judicial makeover opens more doors to wannabe Judges" (6 September 2013) Auckland District Law Society Incorporated <www.adlsi.org.nz〉.

Tom Moore "Born's BAT gets set to fly" (2 January 2014) Commercial Dispute Resolution News <www.cdr-news.com>. 